Skirting the Law: Medicaid Block Grants and Per-Capita Caps in a Pandemic

Laura D. Hermer

Follow this and additional works at: https://open.mitchellhamline.edu/facsch

Part of the Health Law and Policy Commons

Publication Information

14 Saint Louis University Journal of Health Law \& Policy 537 (2021)

This Article is brought to you for free and open access by Mitchell Hamline Open Access. It has been accepted for inclusion in Faculty Scholarship by an authorized administrator of Mitchell Hamline Open Access. For more information, please contact sean.felhofer@mitchellhamline.edu.
MH

MITCHELL | HAMUINE OPEN ACCESS setod of the mitchellhamline.edu 


\title{
Skirting the Law: Medicaid Block Grants and Per-Capita Caps in a Pandemic
}

\begin{abstract}
To what extent can an administration abridge Medicaid's entitlement status by administrative fiat? In the final year of the Trump administration, just before the COVID-19 pandemic, the Centers for Medicare and Medicaid Services (CMS) sought to push the outer bounds of this question by announcing the Healthy Adult Opportunity (HAO) initiative. It invited states to submit $\S 1115$ demonstration applications to cover individuals not eligible for Medicaid benefits under the state' s Medicaid plan-meaning, in many cases, the Affordable Care Act's (ACA's) Medicaid expansion population. Spending on those populations would be capped, not by purporting to waive federal law regarding matching payments under Medicaid-which would clearly exceed the government's authority under $\S 1115(a)(1)$-but rather through application of the demonstration's budget neutrality limit. "Savings"-or the difference between the cap and actual state expenditures under the demonstration-could be used on a variety of otherwise non-matchable state projects.

This Article traces some of the history of this maneuver, showing that the HAO misguidedly seeks to "return" Medicaid to a program it has not been for decades. It furthermore argues that the Trump administration's attempt to cap federal expenditures for certain Medicaid populations in exchange for certain state flexibilities is beyond the administration's legal authority to grant. As this Article shows, the issue turns on how "individuals not eligible for benefits under the state plan" are defined: Are they expansion populations considered to be "receiving medical assistance under a state plan approved under Title XIX," at least for the duration of the demonstration, and hence entitled to all the protections given to categorical and optional Medicaid populations covered under a state plan, or are they simply "regarded" as such for the purpose of expenditures only, and not protections and privileges under the Medicaid statute? A careful reading of the statute, relevant regulations, and recent caselaw show that, at least in the case of the ACA's Medicaid expansion population, the HAO initiative's structure and suggested flexibilities do not comply with the law.
\end{abstract}

\section{Keywords}

Medicaid, Block grants, Healthy Adult Opportunity

\section{Disciplines}

Health Law and Policy 


\title{
SKIRTING THE LAW: MEDICAID BLOCK GRANTS AND PER-CAPITA CAPS IN A PANDEMIC
}

\author{
LAURA D. HERMER*
}

\begin{abstract}
To what extent can an administration abridge Medicaid's entitlement status by administrative fiat? In the final year of the Trump administration, just before the COVID-19 pandemic, the Centers for Medicare and Medicaid Services (CMS) sought to push the outer bounds of this question by announcing the Healthy Adult Opportunity (HAO) initiative. It invited states to submit \$ 1115 demonstration applications to cover individuals not eligible for Medicaid benefits under the state's Medicaid plan-meaning, in many cases, the Affordable Care Act's (ACA's) Medicaid expansion population. Spending on those populations would be capped, not by purporting to waive federal law regarding matching payments under Medicaid - which would clearly exceed the government's authority under $\$ 1115(a)(1)$ - but rather through application of the demonstration's budget neutrality limit. "Savings"-or the difference between the cap and actual state expenditures under the demonstration-could be used on a variety of otherwise non-matchable state projects.

This Article traces some of the history of this maneuver. It argues that the $H A O$ is misguided as a matter of policy, and that the Trump administration's attempt to cap federal expenditures for certain Medicaid populations in exchange for certain state flexibilities is beyond the administration's legal authority to grant. As this Article shows, the issue turns on how "individuals not eligible for benefits under the state plan" are defined: Are they expansion populations considered to be "receiving medical assistance under a state plan approved under Title XIX," at least for the duration of the demonstration, and hence entitled to all the protections given to categorical and optional Medicaid populations covered under a state plan, or are they simply "regarded" as such for the purpose of expenditures only, and not protections and privileges under the Medicaid statute? A careful reading of the statute, relevant regulations, and recent caselaw show that, at least in the case of the ACA's Medicaid expansion population, the HAO initiative's structure and suggested flexibilities do not comply with the law.
\end{abstract}

* Professor of Law, Mitchell Hamline School of Law. Thanks to Sidney Watson for helpful discussion, and to $\mathrm{Nu}$ Vang for able research assistance. 


\section{INTRODUCTION}

Medicaid, which covered a pandemic high of over eighty million Americans in January 2021, is a jointly funded venture between the federal and state governments. ${ }^{1}$ For each dollar a state spends in its Medicaid program, the federal government contributes at least fifty cents. ${ }^{2}$ Federal law requires the federal government to provide these matching funds. ${ }^{3}$ States that spend more money in order to provide more services or cover more people in its Medicaid program get more in federal matching funds. ${ }^{4}$ Federal law provides no cap on expenditures, ${ }^{5}$ nor should it. It is not easy to predict over time how much a state will need to spend on its Medicaid program. ${ }^{6}$ Setting aside natural disasters, economic downturns, and other occasional issues that can lead to high Medicaid spending, states have other spending priorities besides Medicaid and thus must ultimately limit expenditures. ${ }^{7}$

Why, then, might a state be interested in capping the amount of funding the federal government will provide to it? The question becomes particularly relevant in the midst of a pandemic, where the national unemployment rate spiked to $14.7 \%$ in April 2020 and sat at $6.9 \%$ in December 2020 as the pandemic continued. ${ }^{8}$ While millions of Americans lost employer-sponsored coverage in 2020 due to pandemic-related layoffs, most were able to obtain coverage through other means, thanks in no small part to the Affordable Care Act's (ACA's) Medicaid expansion. ${ }^{9}$

1. Bradley Corallo \& Robin Rudowitz, Analysis of Recent National Trends in Medicaid and CHIP Enrollment, KAISER FAM. FOUND. (June 27, 2021), https://www.kff.org/coronavirus-covid19/issue-brief/analysis-of-recent-national-trends-in-medicaid-and-chip-enrollment/.

2. 42 U.S.C. $\S 1396 \mathrm{~d}(\mathrm{~b})$.

3. 42 U.S.C. $\S 1396 b(a)(1) ; 42$ U.S.C. $§ 1396 d(b)(1)$.

4. Andy Schneider, Medicaid and State Budgets: Checking the Facts (Yet Again), GEO. UNIV. HEALTH POL'Y INST. (Feb. 28, 2019), https://ccf.georgetown.edu/2019/02/28/medicaid-andstate-budgets-checking-the-facts-yet-again/.

5. 42 U.S.C. $§ 1396 \mathrm{~d}(\mathrm{u})(4)$.

6. See, e.g., Jeanne M. Lambrew, Making Medicaid a Block Grant Program: An Analysis of the Implications of Past Proposals, 83 MilbanK Q. 41, 55, 57 (2005) (finding that, had the 1995 congressional bill proposing to block-grant Medicaid been granted, federal funding would have been reduced in 2002 by $\$ 15.8$ billion, with substantial variation in individual state impacts).

7. See Medicaid and State Budgets Policy Snapshot, NAT'L CONF. OF STATE LeGiSLATURES 1 (2020), https://www.ncsl.org/Portals/1/Documents/Health/Medicaid-State-Budgets_snapshot _35149.pdf; Edwin Park, State Budget Cuts to Medicaid Means Reduced Federal Funding, Larger Total Cuts, GeO. UnIV. HeALTH POL'y InST. (May 7, 2020), https://ccf.georgetown.edu/2020/05 /07/state-budget-cuts-to-medicaid-means-reduced-federal-funding-larger-total-cuts/.

8. News Release, U.S. Bureau of Lab. Stat., Employment Situation News Release (May 8, 2020), https://www.bls.gov/news.release/archives/empsit_05082020.htm; News Release, U.S. Bureau of Lab. Stat., The Employment Situation-December 2020 at 8 (Jan. 8, 2021), https://www.bls.gov/news.release/pdf/empsit.pdf.

9. See, e.g., Michael Karpman \& Stephen Zuckerman, ACA Offers Protection as the COVID19 Pandemic Erodes Employer Health Insurance Coverage, UrB. Inst. (Nov. 9, 2020), 
As the number of Medicaid beneficiaries increases, however, so does Medicaid spending at both the state and federal levels. ${ }^{10}$ At various times throughout Medicaid's history, some have advocated for eliminating Medicaid's open-ended federal funding in exchange for allowing states increased flexibility in determining various features of their Medicaid programs and the populations eligible for coverage. ${ }^{11}$

In 2019, two states - Tennessee and Utah-submitted applications to the Centers for Medicare and Medicaid Services (CMS) to convert a portion of the federal share of their Medicaid funds to either a block grant or a per capita cap. ${ }^{12}$ A third, Oklahoma, submitted a similar request but later withdrew it. ${ }^{13}$ Shortly following the submission of the first two demonstration applications, CMS issued a letter to State Medicaid Directors soliciting precisely these sorts of applications. ${ }^{14}$ As I will discuss, the Secretary of Health and Human Services (HHS) has no legal authority to grant these waivers.

The Trump administration and these states flagrantly disregarded both statutory authority and the purpose of Medicaid by seeking to cap federal

https://www.urban.org/sites/default/files/103181/aca-offers-protection-as-the-covid-19-pandemicerodes-employer-health-insurance-coverage_0.pdf (finding that, while approximately one in seven working-age adults or their spouse or partner lost employer-sponsored coverage between March and September, 2020, those "losses were mostly offset through increases in Medicaid/CHIP (from 12.8 percent in March/April to 16.8 percent in September) and private nongroup coverage (from 8.5 percent to 11.7 percent)").

10. See Laura Snyder \& Robin Rudowitz, Medicaid Financing: How Does It Work and What Are the Implications?, KAISER FAM. FOUND. 6 (2015), http://files.kff.org/attachment/issue-briefmedicaid-financing-how-does-it-work-and-what-are-the-implications.

11. See, e.g., Lambrew, supra note 6, at 46.

12. Letter from John G. Roberts, Dir., Div. of TennCare, to Judith Cash, Dir., State Demonstrations Grp., Ctrs. for Medicare \& Medicaid Servs. (Nov. 20, 2019), https://www.medic aid.gov/Medicaid-CHIP-Program-Information/By-Topics/Waivers/1115/downloads/tn/tn-tenn care-ii-pa10.pdf; Letter from Gary R. Herbert, Governor, State of Utah, to Alex Azar, Sec'y, Dep't of Health \& Hum. Servs. (July 31, 2019), https://www.medicaid.gov/Medicaid-CHIP-ProgramInformation/By-Topics/Waivers/1115/downloads/ut/ut-per-capita-cap-pa.pdf. In January 2021, the Centers for Medicare and Medicaid Services (CMS) approved in modified form the State of Tennessee's $\S 1115$ demonstration application, imposing an aggregate cap on the state's waiver funds in exchange for, among other things, allowing the state to keep up to fifty-five percent of the federal share of "savings" generated by the state to "reinvest" in certain health programs otherwise funded with state-only money. Ctrs. For Medicare \& Medicaid Servs., TennCare III Medicaid Section 1115 Demonstration, Title XiX No. 11W00369/4, Special Terms and CONDiTIONS, 57-60 (2021).

13. Letter from Melody Anthony, State Medicaid Dir., Okla. Health Care Auth., to James Scott, Program Operations Dir., Ctrs. for Medicare \& Medicaid Servs. (Aug. 11, 2020), https://www.medicaid.gov/medicaid/section-1115-demonstrations/downloads/ok-soonercare-2withdraw-ltr-hoa.pdf.

14. Calder Lynch, Ctrs. For Medicare \& Medicaid Servs., SMD \#20-001, Healthy ADULT OPPORTUNITY INITIATIVE 1 (2020). As of June 2021, the Biden administration has not yet rescinded this letter. See infra, Part IV. 
matching funds in exchange for greater state flexibility, notwithstanding challenges wrought by the pandemic. In doing so, they attempted to further their preferred narratives about government programs, conservative values, and individual deservingness while using the rhetoric of fiscal responsibility and value-based payment programs. ${ }^{15}$ Just because Trump no longer holds the presidency does not mean the endeavors under discussion here are dead. These ideas have a history and will likely continue to surface in the future. ${ }^{16}$

Meanwhile, the COVID-19 pandemic continues to expose the real reason we need generous and stable iterations of Medicaid and other safety net programs such as welfare and tax-based cash assistance programs, ACA premium tax credits, the Supplemental Nutrition Assistance Program (SNAP), unemployment insurance, and housing assistance. In times of individual or collective crisis, coming together to support those in need allows us as individuals and communities to flourish. Without a generous and stable safety net, all of us are vulnerable to harm, no matter how comfortably situated we may temporarily seem. The ACA modified Medicaid and the nongroup health insurance market to provide that safety net. ${ }^{17}$ If there is any time that it makes sense to extend rather than contract the ACA's endeavor, it is now.

This Article considers the Trump administration's and interested states' attempts to transform Medicaid from an open-ended entitlement program into a capped or block-granted welfare plan in which eligibility and benefits for all except the most vulnerable beneficiaries may be limited largely at a state's whim and made contingent on jumping through an ever-growing series of verifications and personal responsibility requirements. ${ }^{18}$ It makes two arguments regarding the Trump administration's project. First, the administration's attempt to cap federal expenditures for certain Medicaid populations is beyond the administration's authority. Second, the Trump administration's endeavor seeks to return the program to something it has not been for many decades, and to which it makes no sense to return. Medicaid has incrementally become far more expansive than its original iteration. At the same time, private health insurance has come to cover, with only a few notable exceptions, many of the same

15. See Abby Goodnough, Trump Administration Unveils a Major Shift in Medicaid, N.Y. TimeS (Jan. 30, 2020), https://www.nytimes.com/2020/01/30/health/medicaid-block-granttrump.html.

16. See, e.g., Laura D. Hermer, Medicaid: Welfare Program of Last Resort, or Safety Net?, 44 Mitchell Hamline L. REV. 1203, 1213-19 (2018) (discussing historical efforts to block-grant Medicaid).

17. Margot Sanger-Katz et al., Obamacare, in Its First Big Test as a Safety Net, Is Holding Up So Far, N.Y. TIMES (Dec. 29, 2020), https://www.nytimes.com/2020/12/29/upshot/obamacarerecession-big-test.html.

18. See Shefali Luthra, Everything You Need to Know About Block Grants - The Heart of GOP's Medicaid Plans, KAISER HEALTH NEWS (Jan. 24, 2017), https://khn.org/news/block-grantsmedicaid-faq/. 
benefits as Medicaid. The Trump administration's prescription is precisely the opposite of the measures we need to take to truly improve the health of our communities and help ensure we have a productive and strong society. In times of crisis such as the current pandemic, we are all vulnerable to job loss, illness, and destitution with all their sequelae. ${ }^{19}$ Without at least a robust safety net, if not instead a single, non-means-tested, non-employment-based health coverage system, we cannot hope to pull together through disaster. Shared sacrifice and a shared future require shared support.

\section{The Past And PResent OF MedicAid AND MEdicaid $§ 1115$ DEMONSTRATION PROJECTS}

Medicaid is a joint federal-state program that provides or pays for health care services for people with low income. ${ }^{20}$ Enacted in 1965, Medicaid's eligibility requirements and benefits, among other items, have changed substantially over time. ${ }^{21}$ At a time when some state and federal actors deny the deservingness of many low-income Americans to participate in Medicaid and claim that Medicaid should be reserved solely for a small subset of the most vulnerable among us, ${ }^{22}$ it is worthwhile to consider the transformations that Medicaid has undergone over the last fifty-six years, and to compare them with some of those changes to those undergone by private coverage during the same period.

\section{A. Medicaid Beneficiaries, Past and Present}

Originally, Medicaid was arguably intended to provide medical care to particular categories of impoverished individuals who needed continued medical support. For its first two decades, Medicaid covered impoverished families eligible for cash welfare through Aid to Families with Dependent Children (AFDC), ${ }^{23}$ and elderly and/or disabled people eligible for cash welfare through Grants to States for Old Age Assistance, ${ }^{24}$ Grants to States for Aid to the Blind, ${ }^{25}$

19. See Antonio Guterres, "This Is, Above All, a Human Crisis That Calls for Solidarity", UNITED NATIONS (Mar. 19, 2020), https://www.un.org/en/un-coronavirus-communications-team /above-all-human-crisis-calls-solidarity.

20. Ctr. ON Budget \& POL'y Priorities, Policy Basics: Introduction to MEdiCAID 1 (2020).

21. Christie Provost \& Paul Hughes, Medicaid: 35 Years of Service, Health Care Fin. ReV., Oct. 2000, at 141, 144.

22. See Simon F. Haeder et al., Lingering Legacies: Public Attitudes About Medicaid Beneficiaries and Work Requirements, 46 J. HeAlth POL., POL'Y \& L. 305, 305-06 (2021).

23. 42 U.S.C. $\S \S 601-09$ (1964) (current version at 42 U.S.C. $\S \S 601-19)$.

24. 42 U.S.C. $\S \S 301-06$ (1964) (current version at 42 U.S.C. $\S \S 301-06$ ).

25. 42 U.S.C. $\S \S 1201-06$ (1964) (current version at 42 U.S.C. $\S \S 1201-06)$. 
Grants to States for Aid to Totally and Permanently Disabled, ${ }^{26}$ or Aid to the Aged, Blind, and Disabled. ${ }^{27}$

Congress never exclusively tethered Medicaid eligibility to eligibility for one of these five cash welfare programs. In the original legislation, Congress made federal Medicaid funding available for individuals who would have been eligible for any of the preceding five programs but for excessive income and/or assets, and who were what we would now term "medically needy"- a status that the original Medicaid statute defined nebulously at best. ${ }^{28}$ Congress added lowincome pregnant women as an eligibility category in 1984, and delinked Medicaid eligibility from cash welfare eligibility for infants, children, pregnant women, and qualified Medicare beneficiaries through a series of amendments to the Social Security Act between 1986 and 1990. ${ }^{29}$ Congress similarly delinked eligibility for adults with dependent children from AFDC in $1996 .{ }^{30}$

As Congress created new eligibility groups and delinked Medicaid eligibility from cash welfare eligibility, the proportion of Medicaid beneficiaries who fit into one of the traditional Medicaid eligibility categories inexorably declined. Between 1988 (when key expansions took place) and 1992, newlyeligible beneficiaries and beneficiaries not eligible for cash welfare accounted for seventy percent of Medicaid's growth. ${ }^{31}$ By 1998, Medicaid beneficiaries who received some form of cash welfare benefits constituted fewer than fortythree percent of all Medicaid beneficiaries. ${ }^{32}$ Following implementation of the ACA's Medicaid expansion in 2014, national figures providing a breakdown of beneficiaries by cash welfare eligibility have become difficult to find. As a proxy, however, in 2019 slightly more than eight million Medicaid beneficiaries received Supplemental Security Income (SSI), ${ }^{33}$ and slightly more than 2.8

26. 42 U.S.C. $\S \S 1351-55$ (1964) (current version at 42 U.S.C. $\S \S 1351-55$ ).

27. 42 U.S.C. $\S \S 1381-85$ (1964) (current version at 42 U.S.C. $\S \S 1381-83 f$ ).

28. 42 U.S.C. $§ 1396 a(a)(10)(B)(i),(a)(17)$ (1965) (current requirements for state plans for medical assistance and eligibility requirements at 42 U.S.C. $\S 1396$ a). Congress soon put income limits on federal financial participation for the medically needy, though those later expanded. See Social Security Amendments of 1967, Pub. L. No. 90-248, sec. 220, § 1903, 81 Stat. 821, 898 (1968) (codified as amended at 42 U.S.C. § 1396b(f)(1)-(3) (1967)).

29. Deficit Reduction Act of 1984, Pub. L. No. 98-369, § 2361, 98 Stat. 494, 1104 (codified as amended in scattered sections of 42 U.S.C.); Medicare Catastrophic Coverage Act of 1988, Pub. L. No. 100-360, $\S 301,102$ Stat. 683, 748 (codified as amended in scattered sections of 42 U.S.C.). The Medicaid provisions of the MCCA remained, despite repeal of other provisions. See also John Holahan et al., Insuring the Poor Through Section 1115 Medicaid Waivers, 14 HEALTH AfFS., no. 1, 1995, at 199, 200.

30. Personal Responsibility and Work Opportunity Reconciliation Act of 1996, Pub. L. No. 104-193, § 114, 110 Stat. 2105, 2177 (codified as amended in 42 U.S.C. $\S$ 1396v, 1396u-1).

31. Teresa A. Coughlin et Al., Medicaid Since 1980: Costs, Coverage, and the Shifting Alliance Between the Federal Government And the States 24-25 (1994).

32. Provost \& Hughes, supra note 21, at 146.

33. Soc. SeC. Admin., SSI ANNUAl StATistical Report, 2019, at 31 tbl.10 (2020). 
million people, including only 756,000 adults, received Temporary Assistance for Needy Families (TANF). ${ }^{34}$ If we assume that every one of those recipients also received Medicaid, then they would constitute just fifteen percent of the 72.9 million Medicaid beneficiaries in $2019 .{ }^{35}$

\section{B. Medicaid Benefits in Relation to Those Typically Offered in Private Coverage}

Medicaid benefits for the fully-eligible ${ }^{36}$ were initially far more comprehensive than those typically covered through contemporaneous private health insurance. They included not only the standard panoply of inpatient and outpatient medical services, but also

(3) "laboratory and x-ray services;

(4) skilled nursing home services ... for individuals twenty-one years of age or older;

(5) physicians' services;

(6) medical care, or other type of remedial care recognized under State law, furnished by licensed practitioners ...;

(7) home health care services;

(8) private duty nursing services;

(9) clinic services;

(10) dental services;

(11) physical therapy and related services;

(12) prescribed drugs, dentures, and prosthetic devices; and eyeglasses prescribed by a physician . . . or optometrist;

(13) other diagnostic, screening, preventive, and rehabilitative services;

(14) inpatient hospital services and skilled nursing home services for individuals sixty-five years of age or over in an institution for tuberculosis or mental diseases; and

(15) any other medical care, and any other type of remedial care recognized under State law, specified by the Secretary ...."37

By contrast, private health insurance policies in 1965 were far more limited in their coverage. Most frequently, they covered only specific types of major

34. Gene Falk \& Patrick A. Landers, Cong. Rsch. Serv., RL32760, The Temporary ASSISTANCE TO NEEDY FAMILIES (TANF) BLOCK GRANT: RESPONSES TO FREQUENTLY ASKED QUESTIONS 12-13 (2021). Individuals transitioning off TANF may retain Medicaid for six to twelve months. 42 U.S.C. § 1396r-6(a).

35. See Medicaid Expansion Enrollment, KAISER FAM. FOUND. (June 2019), https://www.kff .org/health-reform/state-indicator/medicaid-expansion-enrollment/.

36. 42 U.S.C. $\S 1396 u-7(a)(2)(C)$.

37. 42 U.S.C. $\S 1396 d(a)(1)-(15)(1965)$. 
medical care, most notably inpatient hospitalization, surgical services, and/or inpatient physician visits. ${ }^{38}$ One estimate provides that up to eighty-one percent of the population at least had coverage for inpatient hospital care in 1965. ${ }^{39}$ Approximately forty-one percent had coverage for "X-ray and laboratory examinations outside the hospital, thirty-three percent has some coverage of physician visits in the office and home, about twenty-eight percent has some coverage of drugs, twenty-nine percent private-duty nursing, thirty-one percent visiting-nurse service, and about five percent nursing-home care." ${ }^{40}$ About two percent of the population had some form of dental insurance coverage. ${ }^{41}$

By the 1990s, while Medicaid benefits had shifted in slight ways, the panoply of benefits commonly covered by private health insurance had broadened. In Medicaid, some new benefits were added and some of the benefits originally mandated for inclusion in state plans became optional, although most states continued to cover them. ${ }^{42}$ Employer-sponsored private coverage, on the other hand, not only had begun its definitive movement toward managed care, but also typically covered more comprehensive benefits than it had in earlier decades, including hospital and surgical services, inpatient and outpatient physician services, laboratory and diagnostic services, pharmaceuticals, and preventive care services. ${ }^{43}$

Starting in 2006, the Deficit Reduction Act of 2005 permitted states to offer less extensive benefits to certain Medicaid beneficiaries otherwise eligible for full benefits. ${ }^{44}$ Interested states could offer "benchmark benefits" to most children, non-elderly adults with dependent children, and pregnant women with incomes exceeding the federal eligibility floor. ${ }^{45}$ States must either use an Federal Employee Health Benefits (FEHB) Program-equivalent plan, state

38. See Louis S. Reed, Private Health Insurance: Coverage and Financial Experience, 1965, SOC. SEC. BULl., Nov. 1966, at 3, 4.

39. Id. at 4-5.

40. Id. at 6.

41. Id. at 6-7.

42. Medicaid "Mandatory" and "Optional" Eligibility and Benefits, KAISER FAM. FOUND. 7 (2001), https://www.kff.org/wp-content/uploads/2001/06/2256-medicaid-e2809cmandatorye2809 d-and-e2809coptionale2809d-eligibility-and-benefits.pdf (noting that nurse midwife, family planning, and rural health services were included as mandatory benefits in 2001, while pharmaceutical, diagnostic, screening, preventative, and rehabilitative services, among others, had become "optional" for states to cover).

43. See, e.g., Jon R. Gabel, Job-Based Health Insurance, 1977-1998: The Accidental System Under Scrutiny, HEALTH AFFS., Nov.-Dec. 1999, at 62, 67-69 (finding, inter alia, that while only four percent of people with private coverage had an HMO plan in 1977, eighty-six percent had an HMO or other form of managed care plan in 1998. Additionally, coverage of prescription drugs ( $87.3 \%$ in 1977 versus $97 \%$ in 1998), outpatient mental health services $(75.4 \%$ in 1977 versus eighty-six percent in 1998), and routine physicals (6.3\% in 1977 versus $84 \%$ in 1998) all increased during the same period).

44. Deficit Reduction Act of 2005, 42 U.S.C. $\S 1396 u-7(a)(1)(A)$ (2006).

45. 42 U.S.C. $\S 1396 u-7(a)(2)(A)-(B)$. 
employee plan, or commercial HMO plan as a benchmark, or may provide a benchmark-equivalent plan that must at least cover the following services: inpatient and outpatient hospital services; physicians' surgical and medical services; laboratory and x-ray services; prescription drugs; mental health services; children's preventive services; and "[o]ther appropriate preventive services, as designated by the Secretary." 46 In keeping with the benchmarks, these benefits often closely resemble private plan benefits.

In 2014, the ACA extended these benchmark benefits to a new category of Medicaid beneficiaries: non-elderly adults with incomes below $133 \%$ of the federal poverty level (FPL) who otherwise did not qualify for Medicaid. ${ }^{47}$ It furthermore required benchmark and benchmark-equivalent benefits to include the ten "essential" health benefits that the ACA also required all private nongroup and small group plans to cover. ${ }^{48}$ While these included many benefits that had long been standard in private plans, they also included ones that had often been less commonly or comprehensively covered, especially in the individual market, such as preventive services, including women's contraceptive services, habilitative and rehabilitative services and devices, and mental health and substance abuse services. ${ }^{49}$ With these changes, the benefit packages of many Medicaid beneficiaries and individuals covered by private insurance have grown increasingly similar.

\section{Medicaid Section 1115 Demonstration Projects}

Section 1115(a) of the Social Security Act permits the federal government to waive certain requirements of Medicaid or other grant-in-aid programs at a

\footnotetext{
46. 42 U.S.C. $\S 1396 u-7(a)(1),(b)(1)-(2)$.

47. 42 U.S.C. $\$ 1396 a(a)(10)(A)(v i i i)$. Under the income definition established by the ACA, $5 \%$ of the household's income is disregarded in determining eligibility, which means that the income limit for the expansion population is effectively $138 \%$. See, e.g., EvELYNE P. Baumrucker et al., Cong. Rsch. Serv., The Use of Modified AdJusted Gross Income (MAGI) in Federal Health Programs 10 (2018) ("Under the Medicaid MAGI incomecounting rules, a state will look at an individual's MAGI, deduct an amount equal to 5\% of FPL (which the law provides as a standard disregard), and compare that income to the new income standards set by each state in coordination with CMS to determine whether the individual meets the program's eligibility requirements." (internal citation omitted)).

48. The Patient Protection and Affordable Care Act $\S 42$ U.S.C. $\S 1396 u-7(b)$; The Patient Protection and Affordable Care Act $\S 1302$ (b), 42 U.S.C. $\S 300 \mathrm{gg}-6$ (a). These benefits are (A) Ambulatory patient services; (B) Emergency services; (C) Hospitalization; (D) Maternity and newborn care; (E) Mental health and substance use disorder services, including behavioral health treatment; (F) Prescription drugs; (G) Rehabilitative and habilitative services and devices; $(\mathrm{H})$ Laboratory services; (I) Preventive and wellness services and chronic disease management; and (J) Pediatric services, including oral and vision care. 42 U.S.C. $§ 18022(b)$.

49. 42 U.S.C. $§ 18022$ (a)-(b). Group health plans, whether fully insured or self-insured, must include preventive health services. 42 U.S.C. $\S 300 \mathrm{gg}-13$ (a).
} 
state's request, to allow the state to experiment with their Medicaid program. ${ }^{50}$ Not all provisions of Medicaid may be waived; rather, only those found in 42 U.S.C. $§ 1396 a$ are eligible for waiver. ${ }^{51}$ Nor are all projects eligible, but rather only those that, in the judgment of the Secretary of HHS, further Medicaid's goals. ${ }^{52}$ For those projects that are approved, $\S 1115(\mathrm{a})(2)$ permits federal matching funds to be expended in connection with them, even though the "costs of such project ... would not otherwise be included as expenditures under section ... 1396b" of Title $42 . .^{33}$

After the consolidation of Medicare and Medicaid into the Health Care Financing Administration (HCFA, now Centers for Medicare and Medicaid Services (CMS)) in 1977, HCFA assumed responsibility for research and demonstration projects. ${ }^{54}$ As described by HCFA's Office of Research, Demonstration, and Statistics in 1980,

The research, demonstration, and evaluation activities . . of HCFA are intended to provide an empirical basis for measuring the impact of health care financing programs upon the beneficiaries, providers, and the economy at large. This purpose is carried out through a wide variety of scientific investigations into the causes of rising health care costs and into methodologies which show potential for decreasing costs with- out adversely affecting quality of care. The results of ... studies, experiments, demonstrations, and evaluations provide essential documentation to be used by policy makers in considering the effectiveness of proposed policy and/or legislative changes on HCFA's primary goal: to encourage the most efficient and effective delivery of health care services to program beneficiaries. ${ }^{55}$

To achieve "efficient and effective" provision of health care services, states have used Medicaid $\S 1115$ waivers for a variety of purposes over the life of the program. Demonstration projects have included testing alternative delivery or financing systems in an effort to hold down costs, sometimes in conjunction with expanding Medicaid eligibility to new populations. ${ }^{56}$ More recently, a

50. 42 U.S.C. $§ 1315(\mathrm{a})(1)$.

51. Id.

52. Id.

53. 42 U.S.C. $§ 1315(a)(2)$. For further discussion of this issue, see infra, Section II.C.

54. Management of and Results Obtained from HCFA's Demonstration, Experiment, and Related Evaluation Activities: Hearing Before the Subcomm. on Oversight of the H. Comm. on Ways and Means, 96th Cong. 11 (1980) (statement of Gregory J. Ahart, Dir. Hum. Res. Div., U.S. Gen. Acct. Off.).

55. Id. at 12-13 (quoting HCFA's Office of Research, Demonstration, and Statistic's statement of purpose).

56. Id. See also Council on Health CARe TeCh., Inst. of Med., Medical TeChnOlogy ASSESSMENT Directory: A Pilot ReFERENCE to ORganizATIONS, ASSESSMENTS, AND INFORMATION RESOURCES 134 (1988); Availability of Funds for Cooperative Agreements and Grants, 52 Fed. Reg. 34,304 (Sept. 10, 1987); Allen Dobson et al., The Role of Federal Waivers in the Health Policy Process, HeAlth AfFs., no. 4, 1992, at 72, 75-76; Medicaid Experience with 
proportionately small but growing number of Medicaid $\S 1115$ demonstrations have been granted for the purpose of extending coverage to the ACA expansion population of non-disabled, non-elderly adults who do not qualify under Section 1931 (providing coverage to adults who meet 1996 AFDC eligibility requirements) while, at the same time, imposing personal responsibility requirements or other restrictions on non-disabled, working-age adults that make it more difficult for them to obtain or maintain Medicaid coverage. ${ }^{57}$

While this latest waiver trend began during the Obama administration, it continued with zeal under Seema Verma's tenure as Administrator of CMS during the Trump administration. ${ }^{58}$ Verma clearly signaled early on in the Trump administration what her conception of Medicaid was and where the expansion population fit into that concept. In an extended interview in 2017 with journalist Louise Radnofsky of the Wall Street Journal, Verma stated that Medicaid "is part of our social safety net," and that "we have an obligation to help those that are less fortunate." 59 At the same time, she said,

$[\mathrm{O}]$ ne of the major, fundamental flaws in the Affordable Care Act was putting able-bodied adults into a program that was designed for disabled people. And if we look at Medicaid before the Affordable Care Act, this program was having problems, growing costs, and if we look at the type of care that people were getting, we know that one-third of doctors won't even accept Medicaid beneficiaries. There's lots of studies out there that show some dubious health outcomes, the famous Oregon study, so, you know, this is a program that was supposed to focus on the most vulnerable. It's having problems. People are . . . and these are folks that are, you know, a low-income senior, a paraplegic, and imagine that a doctor won't see them, because the reimbursement rates were so low, and instead of fixing those issues, we now put a lot more people into the program, you know, over ten million people, into a program that wasn't even designed for this population. ${ }^{60}$

Rather than just "a health insurance card," she stated that non-disabled, nonelderly Medicaid beneficiaries "actually need a program that helps them rise out of poverty and that's what I think the program needs to be flexible enough to accommodate. ..." 61

State Waivers to Promote Cost Control and Access to Care, Before the Subcomm. on Medicaid \& Health Care for Low-Income Fams., S. Comm. on Fin., 104th Cong. 9-10, app. II (1995) (statement of William J. Scanlon, Assoc. Dir., Health Fin. and Pol'y Issues, Health Educ. \& Hum. Servs. Div.).

57. See, e.g., Medicaid Waiver Tracker: Approved and Pending Section 1115 Waivers by State, KAISER FAM. FOUND. (Jan. 26, 2021), https://www.kff.org/medicaid/issue-brief/medicaidwaiver-tracker-approved-and-pending-section-1115-waivers-by-state/.

58. See, e.g., Laura D. Hermer, The Means and Ends of Wellness Programs, 23 J. HeALth CARE L. \& POL'Y 227, 243-44 (2021).

59. Wall Street Journal, The Future of: Health Care, WALl ST. J. VIDEO (Nov. 10, 2017), https://on.wsj.com/2Ejprbs.

60. Id.

61. Id. 
Under Verma's administration, CMS prioritized making Medicaid more tenuously available for the working-age adult population that, along with children, are Medicaid's most numerous beneficiaries. ${ }^{62}$ For instance, CMS released guidelines on January 30, 2020, ${ }^{63}$ for an unusual Medicaid waiver. The "Healthy Adult Opportunity" (HAO) initiative purports to offer states unprecedented flexibility to reduce benefits, raise cost-sharing amounts, and impose personal responsibility requirements on non-aged, adult Medicaid beneficiaries without disabilities. ${ }^{64}$ It also allows states additional flexibility in setting provider reimbursement rates for Medicaid services and demonstrating the adequacy of managed care networks. ${ }^{65}$ Once granted, such a waiver would permit a state to alter these terms without seeking CMS's approval or requiring a state plan amendment. ${ }^{66}$

In exchange, a state would accept a limit to federal funding for that portion of the Medicaid program. ${ }^{67}$ States choose between an aggregate cap, in which total federal funding per year would be capped regardless of enrollment, or a per capita cap, in which funding per beneficiary would be capped. ${ }^{68}$ Funding under the aggregate cap would be based on the prior year's spending for the demonstration populations, increased by a specified "trend rate." ${ }^{69}$ For states opting for a per capita cap, CMS proposes to divide the prior year's Medicaid expenditures for each demonstration group by the actual number of enrollees per group, and then trending the amount forward pursuant to a specified formula. ${ }^{70}$ The proposal would, in other words, convert federal Medicaid funding for interested states into either a block grant or a per capita-capped program.

62. Abby Goodnough, Trump Administration Unveils a Major Shift in Medicaid, N.Y. TIMES (Jan. 30, 2020), https://www.nytimes.com/2020/01/30/health/medicaid-block-grant-trump.html. See Medicaid Enrollment by Age, KAISER FAM. FOUND., https:/www.kff.org/medicaid/stateindicator/medicaid-enrollment-by-age/ (last visited Feb. 8, 2021).

63. LYNCH, supra note 14.

64. See id. at 7, 10, 15.

65. Id. at 8,12 .

66. Id. at $12-13,15$, app. a.

67. Id. at 16 .

68. LYNCH, supra note 14, at 17, 21.

69. Id. at 17. The trend rate, in states opting for an aggregate cap, is the lower of either "the growth rate in the state over the prior five years" or the medical care component of the consumer price index plus one half of a percentage point. $I d$. at 25 . The base amount is calculated using the "most recently available eight consecutive quarters after December 31, 2016, of finalized CMS-64 expenditure data." Id. at 23 . Where a state will be including newly covered populations (most notably for many states, the ACA-expansion population of non-elderly, non-disabled adults without dependent children), CMS will look to a national average of Medicaid expenditures for the population and services, geographic-specific factors, and "other information" in determining the base amount. $I d$.

70. LYNCH, supra note 14, at 21-22. Here, the trend rate uses the lower of either the "growth rate in the state over the prior five years" or the medical care component of the consumer price index. Id. at 25 . 


\section{CAPPING FEDERAL MEDICAID EXPENDITURES}

The HAO initiative may be unusual, but the concept underlying it is not without precedent. Congress unsuccessfully sought to end Medicaid's entitlement status and convert it into block grant funding on several occasions over the last four decades, most recently in 2017. ${ }^{71}$ Additionally, and despite Congress's refusal to amend Medicaid's financing to permit or require such funding, several states have received capped funding for one or more Medicaid populations through $\S 1115$ Medicaid waivers since the early 2000 s. ${ }^{72}$ These waivers fall into two types: capped funding providing limited benefits to a limited subset of a non-standard population, and capped funding for all or a major portion of a state's Medicaid program, including services for mandatory populations. $^{73}$

\section{A. Capped Funding for Limited Population Expansions}

As part of the Health Insurance Flexibility and Accountability waiver initiative, the Bush administration encouraged recipient states to expand coverage to populations not otherwise covered under their state Medicaid plans using funds often gleaned through cuts or additional fees in other portions of the states' Medicaid programs. ${ }^{74}$ As one example, Utah received approval in 2002 for a demonstration instituting the "Utah Primary Care Network." "75 The demonstration allowed the state to use federally-matched Medicaid funds to provide primary care services and emergency care for up to 25,000 working-age adults with incomes of up to $150 \%$ FPL who would not otherwise be eligible for Medicaid. ${ }^{76}$ To help finance it, Utah cut benefits and raised cost-sharing for

71. See S. 1377, Omnibus Reconciliation Act of 1981, 97th Cong. (1981) (enacted); Balanced Budget Act of 1995, H.R. 2491, 104th Cong. (1995) (as vetoed by President); John Holahan \& Alan Weil, Block Grants Are the Wrong Prescription for Medicaid, URB. Inst., May 2003, at 1, 1 (discussing the Bush administration's 2003 block grant proposal for Medicaid); American Health Care Act of 2017, H.R. 1628, 115th Cong. (2017) (as passed in the House).

72. Teresa A. Coughlin \& Stephen Zuckerman, State Responses to New Flexibility in Medicaid, 86 MiLBANK Q. 209, 212, 213 (2008).

73. E.g., Ctrs. for Medicare \& Medicaid Servs., No. 11-W-00145/8, Special Terms AND CONDITIONS, UtAH PRIMARY CARE NETWORK 78 (2017) [hereinafter UTAH PCN]; THE VT. Agency of Hum. Servs. OfF. of Vt. Health Access, Vermont Global Commitment to HEALTH 64 (2005).

74. dfitzgerald, What is HIFA and Why Should We Be Concerned?, NAT'L HEALTH L. Program (July 23, 2013), https://healthlaw.org/resource/what-is-hifa-and-why-should-we-beconcerned/.

75. Letter from Thomas A. Scully, Adm'r, Ctrs. for Medicare \& Medicaid Servs., to Rod. L. Betit, Exec. Dir., Utah Dep't of Health (Feb. 8, 2002), https://web.archive.org/web/20100304074 042/http://www.health.utah.gov/pcn/pdf/Approval\%20of\%20Terms\%20\&\%20Conditions.pdf.

76. Ctrs. For MEdicare \& Medicaid Servs., No. 11-W-00145/8, SPECIAl Terms AND CONDITIONS, UtAH PRIMARY CARE NETWORK 7 (2002) (capping enrollment at 9000 childless adults and 16,000 adults with children and providing for a minimum benefit of "all health care 
certain existing beneficiaries - primarily Medicaid parents, at least as planned under the waiver, but later also certain disabled and elderly beneficiaries. ${ }^{77}$ Even after 2014 when Utah could have expanded its Medicaid program to cover most of this population with no cap, the state obtained temporary extensions for the program throughout the remainder of the Obama administration and received a five-year extension in 2017 from the Trump administration. ${ }^{78}$

\section{B. Capped Federal Funding for Most or All State Plan Services}

The second type of demonstration discussed here instituted a total cap on federal matching funds for the state's entire Medicaid program in exchange for elements of flexibility. ${ }^{79}$ In 2005, Vermont faced "at least a $\$ 70$ million dollar deficit in Medicaid" that was projected to grow to nearly $\$ 270$ million in the next biennium. ${ }^{80} \mathrm{At}$ the same time, the state was "committed to preserving — and expanding - the affordable coverage gains" it had made over the past decade. ${ }^{81}$ The demonstration it sought- "Global Commitment to Health" - capped total program expenditures at $\$ 4.7$ billion over the first five-year period initially approved, and made the state at risk for both enrollment trends and per-memberper-month costs exceeding the cap. ${ }^{82}$ In the context of Vermont's program, the

services and laboratory services customarily furnished by or through a general practitioner, family physician, internal medicine physician, obstetrician/gynecologist, or pediatrician”); DIV. OF Healthcare Fin., Utah DeP't of Health, Final Operational Protocols for The PRIMARY CARE NETWORK OF UTAH 11, 16 (2002) (setting the income eligibility limit for the Primary Care Network at $150 \%$ of the federal poverty level)

77. Div. OF HEALTHCARE Fin., supra note 76, at 16 (providing for a "reduced benefit plan for [1931 TANF adults, the medically needy, and those eligible for Transitional Medicaid] that previously received full benefits under the Medicaid State Plan," and cost-sharing for those individuals). See also Caitlin Oppenheimer et al., A Case Study of the Utah Primary Care Network Waiver: Insights into Its Development, Design, and Implementation, KAISER FAM. FOUND. 6, 11 (2006), https://www.kff.org/wp-content/uploads/2013/01/7470.pdf.

78. UTAH PCN, supra note 73, at 3; UtAH DEP'T OF HEALth, No. 11-W-00145/8, UTAH 1115 PRIMARY CARE NETWORK DEMONSTRATION WAIVER 3 (2017) (approving the PCN demonstration through June 30, 2022). In response to a successful state referendum to expand Medicaid to the ACA expansion population, the state legislature approved a limited expansion of full Medicaid state plan benefits to adults earning up to $133 \%$ of the federal poverty level. CTRS. FOR MEDICARE \& Medicaid Servs., No. 11-W-00145/8, Special Terms and Conditions, Utah Primary CARE NETWORK 3 (2019).

79. E.g., VT. AGENCY OF HuM. SERVS., supra note 73, at 10.

80. Id. at 5 .

81. Id.

82. Ctrs. for Medicare \& Medicaid Servs., No. 11-W-00194/1, Special Terms and Conditions, Vermont Global Commitment to Health Section 1115 Demonstration 22 (2005). The waiver did not include long-term care services, which continued under a different waiver until 2015, when it was consolidated under the Global Commitment to Health waiver. See Ctrs. FOR MEdicare \& MedicAid SERvs., No. 11-W-00191/6, Vermont ChOices FOR CARE FACT SHEET 22 (2015). While prior waiver approvals continued to put the state at risk for both caseload and per-member-per-month (PMPM) costs, even through the Great Recession, the current 
original cap was relatively generous, as it provided the state with more federal funding per year than the federal government would otherwise have been estimated to have spent over the same period without a cap. ${ }^{83}$ Its practical effects on the program's administration, however, were minimal. ${ }^{84}$ The state received federal matching funds through the standard process. ${ }^{85}$ The Special Terms and Conditions merely provide that, "[i]f at the end of the demonstration period the budget neutrality provision has been exceeded, the excess Federal funds will be returned to CMS." $" 86$

version of the waiver puts the state at risk only for PMPM costs in excess of the cap, but not for the caseload. See Ctrs. for Medicare \& Medicaid Servs., No. 11-W-00194/1, Special Terms and Conditions, Vermont Global Commitment to Health Section 1115 DEMONSTRATION 25 (2011). Starting in 2017, Vermont was no longer at risk for changes in enrollment. See Ctrs. FOR MedicAre \& Medicaid ServS., No. 11-W-00194/1, WAiver Authority, Vermont Global Commitment to Health Section 1115 Demonstration 43 (2017).

83. Vt. Agency of Hum. Servs., Summary Overview: Global Commitment to Health MEDiCAID 1115 Demonstration Waiver 4 (2005) ("Projections are that we will only spend $\$ 4.18$ billion over the next five years for our current enrollees and programs, so there is still room in the waiver cap, or $\$ 4.7$ billion, to handle higher costs or an increase in enrollees. Also, currently we don't even have the General Fund dollars needed to support the full $\$ 4.18$ million [sic] for existing Medicaid services, so reaching the $\$ 4.7$ billion target would be challenging.").

84. Vt. Agency of Hum. Servs., Global Commitment to Health 11-W-00194/1 ANNUAL REPORT FOR FFY 06: OCTOBER 1, 2005 TO SEPTEMBER 31, 200610 (2007). Operationally, however, the state reported some initial difficulties in adjusting to living under one overall cap rather than having different programs siloed. In its first annual evaluation report, it noted that "One particular challenge for programs is that rather than living under and managing separate and discrete caps, all Medicaid programs live under one cap; therefore the impact of a change in Medicaid allocation in one area immediately ripples across all areas. Each department's spending is more directly and immediately interrelated with all other's spending. Closely related to this is the challenge of managing growth across programs that grow unevenly or unpredictably and across the two largest (budget-wise) Agencies of state government (AHS and DOE). This includes managing federal entitlements which cannot be limited alongside discretionary and state mandated spending." Id.

85. Ctrs. FOR MedicARE \& MEdicAid Servs., No. 11-W-00194/1, SPECIAL TERMS AND Conditions, Vermont Global Commitment to Health SeCtion 1115 Demonstration 20 21 (2005).

86. Id. at 22. Longstanding CMS policy provides that section 1115 demonstrations must be budget-neutral to the federal government. See, e.g., Gen. ACCOUnTABILiTy OfF., MedicAid Demonstration WaIVERs: APPROVAL Process Raises COST CONCERNS AND LACKS TRANSPARENCY 1-2 (“Under Department of Health and Human Services (HHS) policy, section 1115 demonstrations should not be approved unless they are budget neutral to the federal government; that is, the federal government will spend no more under a state's demonstration than it would have spent without the demonstration."). As a part of the demonstration application and approval process, states must provide projections of what their programs would cost both with the waiver and without the waiver. Id. at 9 . If the demonstration is approved, then, to the extent that the state underspends its "without waiver" projections over the demonstration, that amount is counted as "savings." Id. at 7-8. Moreover, to the extent a state overspends this amount, the state is supposed to refund the excess federal share to the federal government. GEN. ACCOUNTABILITY 
Through the demonstration, Vermont gained a number of flexibilities. It established its Medicaid agency, the Office of Vermont Health Access, as a public managed care organization to run its Medicaid program and receive from the state a capitated rate for delivery of services ${ }^{87}$ Any difference between the revenues, both state and federal, projected to run the program without the waiver and the amount it actually spends on the program with the waiver, which is still in effect today, can be used to expand capacity in the state's other health-related endeavors not typically fundable using federal Medicaid dollars. ${ }^{88}$ The state also gained the ability to make changes to its Medicaid program, including expansions or contractions to eligibility and/or benefits for existing optional and non-traditional populations (such as the uninsured, working-age adults without dependents whom the program covered), within parameters set by the Special Terms and Conditions of the project. ${ }^{89}$

OfF., Medicaid Demonstration Waivers: Recent HHS Approvals Continue to Raise COST AND OVERSIGHT CONCERNS 17, n.31 (2008) (“In 2006, HHS developed a plan intended to mitigate federal risk with respect to budget neutrality of section 1115 demonstrations, once approved. This plan includes HHS reviews of spending under the approved demonstrations to ensure that the spending complies with the predetermined spending ceilings that HHS approved. OMB incorporated these reviews as a performance metric in its 2006 assessment of Medicaid under the Program Assessment Rating Tool. In 2007, HHS required Wisconsin to return \$10.2 million to the federal government after notifying the state that it had exceeded spending limits for its previously approved section 1115 demonstration.").

87. CTRS. FOR MedicAre \& Medicaid Servs., supra note 85, at 16. See also Vt. AgEnCy OF HUM. SERVS., supra note 83 , at 2.

88. CTRS. FOR MEDICARE \& MEDICAID SERVS., supra note 85, at 17 ("Provided that OVHA's contractual obligation to the populations covered under the Demonstration is met, any revenue from capitation payments related to the beneficiaries covered under this demonstration may only be used for the following purposes: Reduce the rate of uninsured and/or underinsured in Vermont; Increase the access of quality health care to uninsured, underinsured, and Medicaid beneficiaries; Provide public health approaches to improve the health outcomes and the quality of life for Medicaideligible individuals in Vermont; and Encourage the formation and maintenance of public-private partnerships in health care.”); VT. AGENCY OF HUM. SERVS., supra note 83, at 3 (“A primary fiscal advantage to the MCO model is that the MCO can invest in health services irrespective of their current funding source, as long as they are responsible investments that provide necessary health care services for Vermonters. This will enable Vermont to bring in an estimated $\$ 135$ to $\$ 165$ million in new federal funds .... The waiver also provides the state with the ability to be more flexible in the way it uses its Medicaid resources because we are no longer bound by the traditional Medicaid rules. Examples of this flexibility include utilization of creative payment mechanisms (e.g., case rates, capitation, combining funding streams for different populations) rather than feefor-service to pay for services not traditionally reimbursable through Medicaid (e.g., consultation for pediatricians by psychiatrists regarding mental health issues) and investment in innovative programmatic initiatives (e.g., the Chronic Care Initiative and prevention programs).”).

89. See Ctrs. For Medicare \& Medicaid Servs. Special Terms and Conditions, Vermont Global Commitment to Health Section 1115 Demonstration 2-3, 15 (2005) (describing the state's ability to change benefits and eligibility for non-mandatory populations and noting that changes to the waiver should occur at the same time each year, should be approved by 
Rhode Island's Global Consumer Compact § 1115 Medicaid demonstration consolidated the state's existing waiver programs and set a global, capped budget for all of its Medicaid populations and services in exchange for increased flexibility to manage Medicaid costs and services across its program..${ }^{90}$ Centers for Medicare and Medicaid Services set the initial total cap at $\$ 12.075$ billion over the first five years of the waiver, lower than Rhode Island's request of $\$ 12.359$ billion. ${ }^{91}$ As with Vermont's waiver, Rhode Island's waiver utilized the standard Medicaid funding process. ${ }^{92}$ Also similar to Vermont's waiver, Rhode Island was at risk for both enrollment and per-member-per-month cost trends in excess of the cap..$^{93}$ Despite the global budget, the Terms and Conditions of the demonstration required the state to separately evaluate historical Rhode Island Medicaid programs such as RIte Care and RIte Share, among other reporting requirements. ${ }^{94}$

Under the demonstration, Rhode Island was able to consolidate its existing home and community-based services waivers and, in the process, revamp its long-term care program. ${ }^{95}$ It also gained, among other flexibilities, the ability to make changes to general operating procedures, add or eliminate optional state plan benefits, make limited changes in amount, duration, and scope of state plan benefits, and change cost-sharing amounts up to federal limits with only abbreviated notice to CMS. ${ }^{96}$

the Vermont Legislature, and must be submitted to CMS in the form of amendments to the state Medicaid plan).

90. Ctrs. FOR Medicare \& MedicAid Servs., 11-W-00242/1, Special Terms AND Conditions, Rhode Island Global Consumer Choice Compact Section 1115 DEMONSTRATION 2-3, 44 (2009).

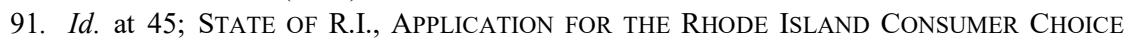
GLOBAL COMPACT WAIVER 47 (2008).

92. CTRS. FOR MEDICARE \& MEDICAID SERVS., supra note 90, at 41. ("The standard Medicaid funding process must be used during the Demonstration. Rhode Island must estimate matchable Demonstration expenditures (total computable and Federal share) subject to the budget neutrality agreement and separately report these expenditures by quarter for each Federal fiscal year on the Form CMS-37 for both the Medical Assistance Payments (MAP) and State and Local Administration Costs (ADM). CMS shall make Federal funds available based upon the State's estimate, as approved by CMS. Within 30 days after the end of each quarter, the State must submit the Form CMS-64 quarterly Medicaid expenditure report, showing Medicaid expenditures made in the quarter just ended. CMS shall reconcile expenditures reported on the Form CMS-64 with Federal funding previously made available to the State, and include the reconciling adjustment in the finalization of the grant award to the State.").

93. Id. at 45. Also like Vermont's waiver, Rhode Island is no longer at risk for changes in enrollment. Ctrs. FOR Medicare \& Medicaid Servis., 11-W-00242/1, Waiver List, Rhode ISLAND COMPREHENSIVE DEMONSTRATION 103-04 (2019).

94. CTRS. FOR MEDICARE \& MEDICAID SERVS., supra note 90, at 46-47.

95. See id. at 23 .

96. Id. at $7-10$. 
Notably, while both Vermont's and Rhode Island's demonstration projects still exist, neither state remains at risk for unexpected changes in enrollment. ${ }^{97}$ Rhode Island expressly requested an end to such risk in its 2013 demonstration extension request. ${ }^{98}$ Both states remain at risk for expenditures in excess of their respective project's per capita cap, but only so that "the demonstration expenditures do not exceed the levels that would have been realized had there been no demonstration." 99 The latter provision is not unique to Vermont's or Rhode Island's demonstrations, but rather is standard in the special terms and conditions for $\S 1115$ demonstration projects. ${ }^{100}$ In this connection, it is notable

97. Ctrs. For Medicare \& Medicaid Servs., No. 11-W-00194/1, Waiver Authority, Vermont Global Commitment to Health Section 1115 Demonstration 35 (2017) [hereinafter VT. WAIVER AUTHORITY] ("Vermont will not be at risk for changing economic conditions which impact enrollment levels. However, by placing Vermont at risk for the per capita costs for demonstration enrollees, CMS assures that the federal demonstration expenditures do not exceed the level of expenditures that would have occurred had there been no demonstration."); Ctrs. FOR Medicare \& Medicaid SERvs., No. 11-W-00242/1, SPECIAL Terms AND Conditions, Rhode IsLand Global CONSUmer CHOICE COMPACt SeCtion 1115 DEMONSTRATION 52 (2013) [hereinafter R.I. SpeCial TERMS AND CONDitions] ("Effective January 1,2014 , the state will be at risk for the per capita cost for demonstration populations as defined in STC 20, but not at risk for the number of participants in the demonstration population. By providing FFP without regard to enrollment in the demonstration populations, CMS will not place the state at risk for changing economic conditions that impact enrollment levels. However, by placing the state at risk for the per capita costs of current eligibles, CMS assures that the demonstration expenditures do not exceed the levels that would have been realized had there been no demonstration.”).

98. State of R.I., ReQuest to Extend the Rhode Island 1115 Research and Demonstration Waiver Project No. 11-W-00242/1 4 (2013) (“This extension request seeks to remove the federal funding cap from this Demonstration and replace it with a more traditional budget neutrality arrangement. We look forward to working with CMS to ensure the new arrangement is reasonable and does not jeopardize the State's ability to continue with previously approved or new requests for [costs not otherwise matchable (CNOM)] expenditures.").

99. R.I. SPECIAL TERMS AND CONDITIONS, supra note 97.

100. See, e.g., IOWACARE, SPECIAL TERMS AND CONDITIONS, NO. 11-W-00189/7, at 14, 17 18 (2013) (providing that "CMS shall provide Federal Financial Participation (FFP) for allowable demonstration expenditures only as long as they do not exceed the pre-defined limits on the costs incurred as specified in section X (Monitoring Budget Neutrality)," and stating that, "[i]f at the end of this demonstration period the budget neutrality limit has been exceeded, the state assures CMS that the excess federal funds shall be returned to CMS"); Healthy Mich., SECtion 1115 Demonstration, Special Terms and Conditions, No. 11-W-00245/5, at 26, 34 (2013) (providing that "CMS shall provide Title XIX FFP for allowable demonstration expenditures, only as long as they do not exceed the pre-defined limits on the costs incurred, as specified in Section XIII of the STCs," and that "If for any DY the state receives FFP in excess of the Annual Limit, the state must return the excess funds to CMS"); CAL. MEDI-CAL, 2020 DEMONSTRATION, SPECIAL TERMS AND CONDITIONS, NO. 11-W-00193/9, at 147 (2020), (providing that "[t]he CMS will provide FFP for allowable demonstration expenditures only as long as they do not exceed the predefined limits on the costs incurred as specified in Section XI (Monitoring Budget Neutrality)," and that "[i]f the budget neutrality expenditure limit defined in STC 197 has been exceeded at the 
that, according to the General Accountability Office, $\S 1115$ budget neutrality requirements have only once been enforced against a state. ${ }^{101}$

\section{Block Grant Redux: CMS's "Healthy Adult Opportunity" Solicitation}

The capped $\S 1115$ demonstration programs of the Bush administrationUtah's primary care program for uninsured, working-age adults, Vermont's Global Commitment to Health, and Rhode Island's Global Consumer Choice demonstration-arose under circumstances that were entirely different than those in which the Trump administration proposed its HAO demonstration template in January 2020. During the 2000s Medicaid simply was not available to the vast majority of uninsured working-age adults ${ }^{102}$ because they did not fall into any eligibility category approved by Congress at that time. ${ }^{103}$

After the ACA's Medicaid expansion went into effect in 2014, low-income, working-age, uninsured adults could obtain coverage, as long as they lived in a state that chose to expand Medicaid. ${ }^{104}$ Initially, only twenty-four states participated in the expansion. ${ }^{105}$ Those that did received a $100 \%$ Federal Medical Assistance Percentage (FMAP) for the expansion population's Medicaid expenditures for the first two years, reducing over time to $90 \% .{ }^{106}$ The availability of Medicaid for formerly uninsured adults in expansion states led to reduced psychological stress in the expansion population, ${ }^{107}$ better access to

end of the demonstration extension period (including Savings Phase-Out), the excess Federal funds must be returned to CMS").

101. See, e.g., Gen. ACCOUnTABiLity OfF., Medicaid Demonstrations: Federal ACtion NEEDED to IMPRove Oversight OF SPENDing 19 (2017) (noting that "in 2007, CMS found that Wisconsin exceeded its demonstration spending limit and required the state to return $\$ 10.2$ million to the federal government").

102. KeVin Quinn et Al., The Commonwealth Fund, On Their Own: Young Adults LiVing Without HeALTh InSURANCE (2000).

103. Provost \& Hughes, supra note 21 , at 142 . While Rhode Island's demonstration did not expand coverage to this population, Vermont's did and Utah's expanded partial coverage to a capped number. Compare CTRS. FOR MEDICARE \& MEDICAID SERVS., supra note 93, at 3-5, with Vt. WAiver Authority, supra note 97, at 10 and Ctrs. For Medicare \& MEdiCAid Servs., supra note 76 , at 7 .

104. Rachel Garfield et al., The Coverage Gap: Uninsured Poor Adults in States That Do Not Expand Medicaid, KAISER FAM. FOUND. (2021), https://www.kff.org/medicaid/issue-brief/thecoverage-gap-uninsured-poor-adults-in-states-that-do-not-expand-medicaid/.

105. See Status of State Action on the Medicaid Expansion Decision, KAISER FAM. FOUND., https://www.kff.org/state-category/affordable-care-act/medicaid-and-health-reform-healthreform/ (under the "Medicaid and Health Reform Heading," click "Status of State Action on the Medicaid Expansion Decision") (last visited Jan. 31, 2021).

106. Robin Rudowitz et al., Medicaid Financing: The Basics, KAISER FAM. FOUnD. 2 (2019), http://files.kff.org/attachment/Issue-Brief-Medicaid-Financing-The-Basics.

107. See, e.g., Amy Finkelstein et al., The Oregon Health Insurance Experiment: Evidence from the First Year, 127 Q. J. ECON. 1057, 1095 (2012) (finding that Oregonians who received Medicaid through a state lottery were ten percent more likely to screen negative for depression than the 
health care, ${ }^{108}$ including preventive care, ${ }^{109}$ and more stable operating margins for hospitals, among other benefits. ${ }^{110}$ There is no evidence that obtaining Medicaid coverage induced new beneficiaries to quit their jobs or refrain from seeking work. Studies found that, while the Medicaid expansion significantly increased coverage, it had little effect on the labor supply. ${ }^{111}$ As one study observed, and without detracting from a larger conception of the value of Medicaid benefits, this is not a surprising finding, given the low average annual value of Medicaid benefits for the average expansion adult. ${ }^{12}$

In short, while the ACA's Medicaid expansion had only three years of operation under the Obama administration, it appeared to be working reasonably well. The Trump administration, however, did not see the matter that way. It took issue with the extension of public coverage to anyone other than the frailest

control mean, and about twenty-five percent more likely to report good, very good, or excellent health than the control mean); Katherine Baicker et al., The Oregon Experiment: Effects of Medicaid on Clinical Outcomes, 368 NEw ENG. J. MED. 1713, 1717 (2013) (finding a nearly eight percent improvement in health-related quality of life and happiness among Oregonians who received Medicaid through a state lottery as compared to the control mean).

108. See, e.g., Jonathan Gruber \& Benjamin D. Sommers, The Affordable Care Act's Effects on Patients, Providers, and the Economy: What We've Learned So Far 35 (Nat'l Bureau of Econ. Rsch., Working Paper No. 25932, 2019), https://www.nber.org/system/files/working_papers/w25 932/w25932.pdf (finding, inter alia, that some of the ACA's Medicaid expansion was sometimes associated with increased access to dental services and increased diagnoses of chronic conditions); Medicaid Expansion Impacts on Insurance Coverage and Access to Care, DEP'T OF HEALTH \& Hum. Servs., OfF. OF the Assistant SeC'y fOR Plan. \& Evaluation 4, 6 (2017), https://aspe.hhs.gov/system/files/pdf/255516/medicaidexpansion.pdf [hereinafter Expansion Impacts on Coverage \& Access] (finding an association between Medicaid expansion and having a usual source of health care, as well as an increase in community health center visits).

109. Expansion Impacts on Coverage \& Access, supra note 108, at 6.

110. See, e.g., Genevieve P. Kanter et al., Association of State Medicaid Expansion with Hospital Community Benefit Spending, JAMA NeTwORK Open, May 2020, at 8 (finding that nonurban and urban hospitals experienced large and moderate declines, respectively, in charity and subsidized care spending following Medicaid expansion).

111. See, e.g., Thomas C. Buchmueller et al., Medicaid Expansion and the Unemployed 35-36 (Nat'1 Bureau of Econ. Rsch., Working Paper No. 26553, 2019), https://www.nber.org/system/files /workingpapers/w26553/w26553.pdf ("Our difference-in-difference tests show no meaningful effects of the Medicaid expansions on job finding but a reduction in labor force exits for some groups (parents and the short-term unemployed). This suggests no moral hazard effects on labor market behavior arising from the expansions, and in fact modest positive effects on labor force attachment."); Robert Kaestner et al., Effects of ACA Medicaid Expansions on Health Insurance Coverage and Labor Supply 27-28 (Nat'l Bureau of Econ. Rsch., Working Paper No. 21836, 2015), https://www.nber.org/system/files/working_papers/w21836/w21836.pdf ("Estimates of the effect of Medicaid on labor supply were, in general, small and not statistically significant. In fact, most estimates of the effect of the Medicaid expansions on labor supply were positive. Overall, there was very little evidence that the Medicaid expansions decreased work effort. Moreover, confidence intervals associated with estimates rule out modest to large decreases in employment and hours of work in response to the Medicaid expansions.").

112. See Buchmueller et al., supra note 111, at 33. 
of our population: the aged and disabled, or those whom CMS Administrator Seema Verma described as "aged, blind, disabled—people that are going to be on the program for the rest of their lives." 113 Administrator Verma has long advocated for the disentitlement of "able-bodied," non-elderly people to Medicaid, ${ }^{114}$ and used her tenure in the Trump administration to push endeavors intended to further this end. ${ }^{115}$

The Trump administration's HAO is a continuation of this trend. The policy explicitly targets the ACA's Medicaid expansion population in states that either do not already cover them or that do but that "elect[] to end coverage" for them, with an eye toward potentially reducing income eligibility, presumptive or retroactive eligibility, and/or benefits, and imposing cost-sharing. ${ }^{16}$ Proposed flexibilities also include the ability to make certain administrative changes, such as changes in provider reimbursement, without filing a state plan amendment or obtaining prior approval from CMS. ${ }^{117}$ Yet there are no flexibilities mentioned in the SMD letter describing the solicitation that could not be provided through a standard $§ 1115$ waiver, other than those which may not be accomplished at all

113. Wall Street Journal, supra note 59.

114. See, e.g., J.K. Wall, Pence Still Angling to Use Healthy Indiana Plan to Expand Medicaid, INDIANAPOLIS BUS. J. (Feb. 23, 2013), https://www.ibj.com/articles/39757-pence-still-angling-touse-healthy-indiana-plan-to-expand-medicaid (noting Verma's statement during a luncheon speech on health reform and the Healthy Indiana Plan that "[i]t's that we require people to make contributions [to health savings accounts under the Healthy Indiana Plan]. That really flies in the face of the entitlement thing.").

115. Letter from Thomas E. Price, Sec'y, Health \& Hum. Servs., and Seema Verma, Adm'r, Ctrs. for Medicare \& Medicaid Servs., to State Governors 2 (Mar. 14, 2017), https://www.hhs.gov /sites/default/files/sec-price-admin-verma-ltr.pdf (informing governors of their interest in Medicaid demonstrations and programs that increase employment and community engagement and "align" Medicaid and private plans for "low-income Americans"); CTRS. FOR MEDICARE \& MEDICAID SERVS., SMD \# 18-002, RE: OpPORTUNITIES TO PROMOTE WORK AND COMMUNITY ENGagement AMONG MEDICAID BENEFICIARIES 3 (Jan. 30, 2018) (notifying state Medicaid directors of CMS's interest in receiving $\S 1115$ demonstration proposals that "require eligible adult beneficiaries to engage in work or community engagement activities (e.g., skills training, education, job search, caregiving, volunteer service) in order to determine whether those requirements assist beneficiaries in obtaining sustainable employment or other productive community engagement and whether sustained employment or other productive community engagement leads to improved health outcomes").

116. LynCh, supra note 14, at 1, 3; Ctrs. For Medicare \& Medicaid Servs., Healthy Adult Opportunity (HAO) Section 115 Demonstration Application Guidance \& TEMPlate 4, 19 (2020) (stating that "[t]his demonstration opportunity is available to all states as a mechanism to provide maximum flexibility for covering adults under age 65 who qualify for Medicaid on a basis other than disability or need for long term care services and supports and who are not covered under the Medicaid state plan, including covering all individuals described in the new adult group at section 1902(a)(10)(A)(i)(VIII) of the Act and 42 CFR 435.119 (the new adult group)," and providing for a range of options regarding benefits and cost-sharing).

117. LYNCH, supra note 14 , at 3. 
under the present law governing Medicaid. ${ }^{118}$ Those latter items include, most notably, the proposed change in funding from an unlimited federal match to either a block grant or a per capita cap. ${ }^{119}$

CMS asserts that HAO waivers can be authorized under $\S 1115(\mathrm{a})(2)$ of the Social Security Act. ${ }^{120}$ Section 1115(a)(2), among other things, allows the Secretary to include "costs not otherwise matchable" (CNOM) as federally matchable costs under a $\S 1115$ waiver. ${ }^{121}$ In the second half of Administrator Verma's tenure, CMS accelerated the use and promotion of $\S 1115(\mathrm{a})(2)$ as an independent source of demonstration authority. ${ }^{122}$ Section 1115 (a) provides in relevant part that:

In the case of any experimental, pilot, or demonstration project which, in the judgment of the Secretary, is likely to assist in promoting the objectives of title ... XIX ... in a State or States-

(1) the Secretary may waive compliance with any of the requirements of section $\ldots 1902, \ldots$ to the extent and for the period he finds necessary to enable such State or States to carry out such project, and

(2)(A) costs of such project which would not otherwise be included as expenditures under section ... 1903, ... shall, to the extent and for the period prescribed by the Secretary, be regarded as expenditures under the State plan or

118. See, e.g., id. at 2 (touting HAO initiative "benefits" such as "[t]he ability to cover adults who qualify for Medicaid on a basis other than disability or need for long-term care services and supports and who are not covered under the state plan, including covering all individuals described in section 1902(a)(10)(A)(i)(VIII) of the Act and 42 CFR 435.119 ("adult group") using section 1115(a)(2) expenditure authority at the . . FMAP that would apply if they were covered under the state plan; [p]roviding populations covered under an HAO demonstration with coverage more consistent with insurance benefits provided through the Exchanges, rather than the traditional Medicaid benefit package; [and] [t] he ability to pay for services that cannot traditionally be funded by Medicaid, including those designed to address certain health determinants, such as enhanced case management services that link individuals to housing or other supports ...."). Touted flexibilities that are likely illegal include work requirements, restricting free choice of provider for women's health services, and restricting coverage of FQHC services. See id. at 5, 13-14, 39-42.

119. Id. at 16

120. Id. at 1; CTRS. For MEDICARE \& MEDICAID SERVS., supra note 116, at 33 (stating that " $[t]$ he Medicaid program flexibilities requested by the state in this HAO demonstration application are designed to be provided specifically pursuant to expenditure authority under section 1115(a)(2) of the Act, without the need for section 1115(a)(1) waiver authorities" and directing the state to specify any other authority it believes might be needed for any policy options it elects).

121. 42 U.S.C. $\S 1315(a)(2)$.

122. See, e.g., Andy Schneider, Medicaid Work Requirements and Beyond: CMS Administrator Tries a New Work-Around, GeO. UnIV. HeAlth PoL'Y INST. (Jan. 30, 2020), https://ccf.george town.edu/2020/01/30/medicaid-work-requirements-and-beyond-cms-administrator-tries-a-newwork-around/ (discussing CMS's citation solely of $\S 1115(\mathrm{a})(2)$ authority in granting work requirement demonstration projects in South Carolina and Utah in 2019). 
plans approved under such title, or for administration of such State plan or plans, as may be appropriate ... ${ }^{123}$

Section 1115(a)(1) empowers the Secretary to waive compliance with federal Medicaid requirements found in section 1902 (42 U.S.C. § 1396a). ${ }^{124}$ Section 1115(a)(2) provides that the "costs of such project" not otherwise matchable under Medicaid "shall, to the extent and for the period prescribed by the Secretary, be regarded as expenditures under the state plan ...." 125 A plain reading of sections $1115(\mathrm{a})(1)$ and (a)(2) suggests that the "costs" in question are not ones that may arise through an independent demonstration grant, but rather are incurred in connection with waiver demonstrations. ${ }^{126}$ But even more importantly, as Professor Sidney Watson observed, to interpret § 1115(a)(2) to provide its own source of expenditure authority independent of Title XIX or other relevant Titles would render the "Medicaid statute ... practically meaningless, and the Secretary's discretionary authority practically boundless." 127

This last point seems self-evident. Would Congress really have given an administrative agency unfettered discretion, among other things, to expand federal expenditures - discretion that has only been bounded by the agency's own conventions? ${ }^{128}$ The notion seems absurd. Even the Senate report accompanying the original enactment of $\S 1115$ states that the provision was intended to allow the Secretary to "waive" certain federal-state program requirements "if such project furthers the general objectives of the program[,]" and that "[t]his would mean that the regular Federal participation would be

123. 42 U.S.C. $\S 1315(a)$.

124. 42 U.S.C. $\S 1315(a)(1)$.

125. 42 U.S.C. $\S 1315$ (a)(2).

126. See Jonathan R. Bolton, The Case of the Disappearing Statute: A Legal and Policy Critique of the Use of Section 1115 Waivers to Restructure the Medicaid Program, 37 CoLum. J. L. \& SOC. PROBS. 91, 154 (2003) ("Without section 1115(a)(2), HHS could not provide federal matching funds to states for any expenses incurred in a demonstration project created by the Secretary's use of the waiver power. Hence, the most straightforward interpretation of section 1115(a)(2) is that it is linked with the waiver power and that the invocation of both powers is necessary for the creation of any demonstration projects."); Sidney D. Watson, Premiums and Section 1115 Waivers: What Cost Medicaid Expansion?, 9 St. LouIs U. J. HeAlth L. \& POL'Y 265, 293-94 n.162 (2016) ("In two cases involving HIFA waivers, HHS asserted that Section 1115 (a)(2) allegedly creates an "expenditure authority" that grants the Secretary authority to approve Section 1115 demonstrations not tied to waivers of provisions in Section $1902 \ldots$ However, this argument ignores the text of Section 1115. Section 1115(a)(1) and Section 1115(a)(2) are connected by an 'and' not an 'or.' ... Section 1115(a)(1) gives the Secretary authority to waive provisions in Section 1902 'and' then Section 1115(a)(2) gives the Secretary authority to use federal money to fund the demonstration." (internal citations omitted)).

127. Watson, supra note 126.

128. See, e.g., Medicaid Program; Demonstration Proposals Pursuant to Section 1115(a) of the Social Security Act; Policies and Procedures, 59 Fed. Reg. 49249, 49249 (Sept. 27, 1994) (discussing assessment of budget neutrality in $\S 1115$ demonstration projects). 
available for such projects whether they involve assistance, service, or administrative expenditure." 129 It nowhere suggests that the expenditure authority under $\S 1115(\mathrm{a})(2)$ acted as its own source of demonstration authority, independent of $\S 1115(\mathrm{a})(1)$.

However, not everyone has agreed, most notably including the Department of Health and Human Services. Administrator Verma's attempt to interpret $\S$ 1115(a)(2) as providing its own source of demonstration authority, untethered to Title XIX, where no relevant section of 1902 need be waived, has a history predating her tenure, and has been accepted by several courts with little contest. ${ }^{130}$ As far back as the Senate hearings on the Public Assistance Act of 1962, which contained $\S 1115$, Abraham Ribicoff, Secretary of Health and Human Services, observed that the Kennedy administration wanted Congress to give the Secretary "authority ... to regard otherwise unmatchable expenditure as matchable in the interest of the State's developing imaginative new or experimental approaches to the administration of public assistance." ${ }^{131}$ During the first George W. Bush administration, several courts found the Secretary's

129. S. REP. No. 87-1589 at 19-20 (1962). Apart from such expenditure authority in connection with waiver projects, $\S 1115$ provided only up to $\$ 2$ million to cover costs of projects outside of appropriations for services provided under state plans. Id. at 20. "Projects to be initiated [using this additional funding] are expected to be selectively approved by the Department and to be those which are designed to improve the techniques of administering assistance and the related rehabilitative services under the assistance titles." Id.

130. See, e.g., Spry v. Thompson, 487 F.3d 1272, 1277 (9th Cir. 2007); Newton-Nations v. Betlach, 660 F.3d 370, 379 (9th Cir. 2011). But see Cookeville Reg'l Med. Ctr. v. Thompson, No. Civ.A. 04-1053 JR, 2005 WL 3276219, at*8 (D.D.C. Oct. 28, 2005); Portland Adventist Med. Ctr. v. Thompson, 399 F.3d 1091, 1099 (9th Cir. 2005).

131. Public Assistance Act of 1962: Hearings on H.R. 10606 Before the S. Comm. on Finance, 87th Cong. 69 (1962). 
use of $\S 1115(a)(2)$ in that manner to be nearly unremarkable. ${ }^{132}$ The same was true under the Obama administration. ${ }^{133}$

The independence that this gives the Secretary has led to questions about how to regard Medicaid $\S 1115$ expansion populations - meaning populations not otherwise included in a state's Medicaid state plan - in such demonstrations: are they populations "receiving medical assistance under a state plan approved under Title XIX," 134 at least for the duration of the demonstration, or are they simply "regarded" as such for the purpose of expenditures only? ${ }^{135}$ The question is important. Under the first interpretation, expansion populations would be

132. See, e.g., Cookeville Reg'l Med. Ctr. v. Leavitt, 521 F.3d 844, 848 (D.C. Cir. 2008) ("The Social Security Act sets out the requirements for a patient to be eligible for medical assistance. 42 U.S.C. § 1396d(a). The expansion waiver population does not meet these criteria-generally because their incomes are too high. Likewise, demonstration projects are state plans approved under subchapter XI, not subchapter XIX.”); Spry, 487 F.3d at 1277 (“Expenditures being 'regarded as eligible' for Medicaid for purposes of calculating hospital reimbursement is not the same thing as an individual being 'eligible' for Medicaid benefits.") and Newton-Nations, 660 F.3d 370, 377 ("The district court determined that the Secretary 'invoked 'expenditure authority' under 42 U.S.C. $\S 1315(\mathrm{a})(2)$ in allowing Arizona to offer the expanded coverage. Plaintiffs are not eligible for Medicaid under a state plan so there was no need for a waiver.' Thus, '[s]ections $1396 o$ and $1396 o-$ 1 do not apply to Plaintiffs. Defendants did not act in violation of' these sections."). Only one court that has analyzed the issue in any detail came to the conclusion that section (2)(A) provided no source of demonstration authority independent of $\S 1115$ (a)(1) and did so in an unpublished opinion considering the calculation of DSH funds under law that has since been modified. In that case, Cookeville Regional Medical Center v. Thompson (Cookeville I), Secretary Thompson "argued at length in his briefs that $\S 1115$ gives him 'expenditure authority' under Title $X I$ with which he funds demonstration projects, and that this 'expenditure authority' is 'separate' from Title XIX." Cookeville Regional Medical Center v. Thompson, No. Civ.A. 04-1053 JR, 2005 WL 3276219 at 5 (D.D.C. 2005). However, as the district court pointed out, "[r]ather than establishing an independent authority to direct federal spending, this and the other operative parts of $\S 1115$ explicitly define the Secretary's authority by reference to Title XIX. It is clear that expansion populations become eligible for medical assistance only under a state plan approved under Title XIX, not a separate $\S 1115$ funding mechanism.” Id. at *6. Section 1115, incidentally, does provide for "no more than $\$ 4,000,000$ of the aggregate amount appropriated for payments to States under such titles for any fiscal year beginning after June 30,1967 . . to cover so much of the cost of such projects as is not covered by payments under such titles." 42 U.S.C. $§ 1315$ (a).

133. See, e.g., Newton-Nations, 660 F.3d at 379 ("[T] he Secretary argues that cost-sharing restrictions 'apply only to persons who are both statutorily eligible for Medicaid coverage and identified in the State Medicaid plan.' She argues that '[u]nder the existing State plan, [Plaintiffs] are not eligible for Medicaid and are, instead, an 'expansion population' to which the cost restrictions do not apply."').

134. Portland Adventist Med. Ctr., 399 F.3d at 1099.

135. Spry v. Thompson, 487 F.3d 1272, 1277 (2007) ("The waiver in section 1315 enables state governments to count costs 'which would not otherwise be included' or 'which would not otherwise be permissible use' to be 'regarded as' state plan expenditures and permissible use of funds for purposes of federal reimbursement." (internal citations omitted)). 
entitled to all the protections and privileges given to categorical and optional Medicaid populations. ${ }^{136}$ Under the second, however, they would not. ${ }^{137}$

Few circuits have considered this issue in any detail. In Portland Adventist Medical Center v. Thompson, the Ninth Circuit determined that, while the Secretary has discretion in approving demonstration projects, any expenditures granted through a $\S 1115$ Medicaid demonstration project must be regarded as Title XIX expenditures, and "thus" that " $§ 1115$ expansion populations" must also be regarded "as receiving medical assistance under a state plan approved under Title XIX." ${ }^{138}$ However, in subsequent cases the Ninth Circuit determined that, where a state has made one or more expansion populations eligible for Medicaid under the demonstration rather than under the Medicaid state plan, specific protections Congress provides to mandatory Medicaid populations (such as limits on cost-sharing) are not automatically available for nonmandatory expansion populations, even where the expansion population in question is an optional Medicaid population and thus could be included in a state's Medicaid plan without the use of a waiver. ${ }^{139}$ The Ninth Circuit reasoned in both Spry v. Thompson and Newton-Nations v. Betlach that such populations might not have any coverage at all, absent the waiver, and hence suffer no harm

136. See, e.g., Portland Adventist Med.Ctr., 399 F.3d at 1099 (noting that, while $\S 1115$ "gives the Secretary discretion in approving projects, the provision requires the Secretary to regard expenditures under $\S 1115$ projects designed to assist low-income patients as Title XIX expenditures for the duration of such projects, and therefore to regard $\S 1115$ expansion populations as receiving medical assistance under a state plan approved under Title XIX").

137. See, e.g., Newton-Nations, 660 F.3d at 379 (deferring to the Secretary's interpretation that the expansion population in question, which was not covered under the state plan, was not subject to the cost-sharing limits provided in 42 U.S.C. $\$ 13960$ ).

138. Portland Adventist Med. Ctr., 399 F.3d at 1096, 1099; accord Cookeville Reg'l Med. Ctr., 2005 WL 3276219, at 5. Subsequent Ninth Circuit caselaw, however, has attempted to distinguish between "eligib[ility] to receive benefits under a state plan" and "eligib[ility] for Medicaid." See Spry, 487 F.3d at 1277; Newton-Nations, 660 F.3d at 374-75. Other circuits, moreover, have rejected Portland Adventist's wholesale conclusion that expenditures for Medicaid expansion populations are expenditures under Title XIX tout court. See, e.g., Cookeville Reg'l Med. Ctr., 531 F.3d at 848 ("While [the language in $\S 1115(\mathrm{a})(2)(\mathrm{A})$ ] clearly gives the Secretary control over the duration over the demonstration project, the language may do more. Plausibly, the 'to the extent' language is a grant of discretion to the Secretary to determine which costs or how much of the costs are to be treated as expenditures.").

139. See, e.g., Newton-Nations, 660 F.3d at 379 ("The regulations therefore support the Secretary's interpretation that where, as here, a state has not defined its 'medically needy' population pursuant to the Medicaid Act, persons who are not mandatorily covered by the state plan are expansion populations not protected by the $\S 1396$ o cost-sharing limits. Because $\S 13960$ is ambiguous and 'the Secretary's regulation ... is based on a permissible construction of the statute,' we are obligated to defer to the Secretary's position under the strictures of Chevron deference."). 
by being given benefits under conditions that are not compliant with Medicaid terms applicable to mandatory populations. ${ }^{140}$

Notably, however, the only court to have considered the applicability of this interpretation to the ACA Medicaid expansion population rejected it. In Stewart v. Azar, the State of Kentucky, which had provided Medicaid benefits to the ACA expansion population and had later obtained a $\S 1115$ waiver to impose work requirements on that population, argued that if it could not retain its waiver, it would simply withdraw eligibility from the expansion population. ${ }^{141}$ Kentucky argued that "[t]his route is legally permissible ... because the expansion population is optional and therefore need not receive any coverage." 142 Judge Boasberg of the district court of the District of Columbia, however, disagreed. ${ }^{143} \mathrm{He}$ held that Kentucky had no discretion to treat the ACA expansion population any differently than those traditionally eligible for the program, as Congress made the ACA expansion population a mandatory eligible category of persons. ${ }^{144}$ Kentucky could not, he wrote, "implement the ACA expansion as an à la carte exercise, picking and choosing which of Congress's mandates it wishes to implement." ${ }^{145}$ What is more, he observed that to argue that the Secretary should grant any demonstration application, no matter what it entailed, simply because it offered more coverage than the subject population would have absent the program, would render boundless discretion to the Secretary. ${ }^{146}$

These cases are relevant to the authority of CMS to grant $\S 1115$ demonstration projects that impose a block grant or per capita cap on the federal match of a state's Medicaid expenditures on specific categories of beneficiaries. In the case of waivers purporting to cap the federal match of Vermont's and

140. Spry, 487 F.3d at 1276 ("People in the expansion population are not made worse off by inclusion in a demonstration project less favorable to them than to the categorically and medically needy because, without the demonstration project, they would not be eligible for Medicaid at all."); Newton-Nations, 660 F.3d at 379.

141. Stewart v. Azar, 366 F. Supp. 3d 125, 153 (D.D.C. 2019).

142. Id.

143. Id.

144. Id. Nevertheless, parties appealing two other Medicaid work requirement cases, Gresham v. Azar and Philbrick v. Azar, continue to argue that NFIB v. Sebelius rendered the ACA Medicaid expansion population “optional.” See Philbrick v. Azar, 397 F. Supp. 3d 11, 27 (D.D.C. 2019); Petition for Writ of Certiorari at 23, Azar v. Gresham, 141 S.Ct. 890 (2020) (No. 20-37).

145. Id.

146. Stewart, 366 F. Supp. 3d at 154. Accord Philbrick, 397 F. Supp. 3d at 27 (noting that the Secretary's position "has no limiting principle. Under the Secretary's reasoning, states may threaten to de-expand, or indeed do away with all of, Medicaid if he does not approve whatever waiver of whatever Medicaid requirements they wish to obtain. The Secretary could then always approve those waivers, no matter how few people remain on Medicaid thereafter, because 'any waiver would be coverage promoting compared to a world in which the state offers no coverage at all."” (citing Stewart)). 
Rhode Island's Medicaid expenditures, neither CMS nor the relevant states made any attempt to provide legal justification for the cap while it existed, and no one challenged the cap in court. In the case of CMS's HAO solicitation, however, CMS alleges that $\S 1115(\mathrm{a})(2)(\mathrm{A})$ provides it with authority to grant a demonstration imposing a block grant or per capita cap. ${ }^{147}$ Under Spry and Newton-Nations, if the ACA expansion population is considered optional, as the Trump administration argues, ${ }^{148}$ rather than mandatory, as provided in the statute and under Judge Boasberg's interpretation, ${ }^{149}$ then CMS would arguably act within its authority if it permitted a state to cover the ACA expansion population using a block grant or per capita cap. ${ }^{150}$ All that would matter in that case is whether the expansion population is covered under a state's Medicaid plan at the time of the waiver. ${ }^{151}$ Using this theory, populations not included in a state's Medicaid plan do not enjoy the protections that federal law affords mandatory populations, even if the non-included populations were optional rather than expansion populations and hence could be covered under a Medicaid state plan without the use of a waiver. ${ }^{152}$ If the Secretary could, for example, allow a state to expand limited coverage to otherwise-ineligible populations (e.g., as Utah did in its Primary Care Network program during the Bush administration), then the Secretary arguably could similarly limit federal financial participation with respect to that population as well. ${ }^{153}$ The

147. LYNCH, supra note 14.

148. See, e.g., Petition for Writ of Certiorari, supra note 144, at 5, 23 (alleging that, "[f]ollowing $N F I B$, as many States were evaluating whether to participate in the ACA's expansion of adult eligibility, HHS acknowledged that coverage of the expansion population was optional," and later claiming that, "the majority of Medicaid spending goes toward optional benefits and populations that States have elected but are not required to cover-including, of particular relevance here, the adult- expansion population that became optional as a result of this Court's decision in NFIB."); Letter from Mary C. Mayhew, Deputy Adm'r \& Dir., Ctrs. for Medicare \& Medicaid Servs., to Henry D. Lipman, Medicaid Director, N.H. Dep't of Health \& Hum. Servs., at 2 n.1 (Nov. 30, 2018) ("The optional groups include a new, non-elderly adult population (ACA expansion population or new adult group) that was added to the Act at section 1902(a)(10)(A)(i)(VIII) by the Patient Protection and Affordable Care Act (ACA). Coverage of the ACA expansion population became optional as a result of the Supreme Court's decision in NFIB v. Sebelius, 567 U.S. 519 (2012).”).

149. 42 U.S.C. $§ 1396 a(a)(10)(A)(i)(V I I I) ;$ Stewart, 366 F. Supp. 3d at 153.

150. See Letter from Mary C. Mayhew, supra note 148.

151. LYNCH, supra note 14, at 3 ("The HAO initiative described in this guidance is available to all states as a mechanism to cover populations not covered under their state plan. HAO demonstrations also could be used to extend coverage to populations a state has previously covered in its state plan or under other section 1115 demonstrations, but for whom the state has elected to end coverage. We expect that coverage under an HAO demonstration will focus on adults under age 65 who are not eligible for coverage under the state plan. CMS may consider state requests to include other adult populations who are not eligible for coverage under the state plan.”).

152. See Spry, 487 F.3d at 1274; Newton-Nations, 660 F.3d at 379.

153. Oppenheimer et al., supra note 77. 
rationalization in this race to the bottom is that some coverage is better than no coverage at all. ${ }^{154}$

Were such a theory correct, the Secretary would indeed be able to "return" Medicaid to its alleged original "focus on the most vulnerable" and to those who "are going to be on the program for the rest of their lives." ${ }^{155}$ States that excluded from their state Medicaid plans all non-elderly adults who did not otherwise qualify as a member of a mandatory Medicaid population could propose to include such populations in limited number with limited benefits, and with any eligibility requirements that would allegedly "allow states to experiment with innovative means of deploying their limited state resources in ways that may allow them to provide services beyond the legal minimum." 156

Yet the ACA expansion population is not an "optional" population. It is mandatory, and continues to be described as such in the Medicaid statute. ${ }^{157}$ The Supreme Court did not transform the population into an optional one in NFIB $v$. Sebelius. ${ }^{158}$ Rather, "[t] he case held only that Congress was "not free ... to penalize States that choose not to participate in [the expansion] by taking away their existing Medicaid funding." ${ }^{159}$ As such, allowing the Secretary to make an end run around Congress's goals in enacting and amending the Medicaid statute is both unreasonable and unwarranted. As Judge Boasberg wrote in Stewart v. Azar, § 1115 "does not turn the comprehensive Medicaid program that Congress designed into a buffet for states." 160

As such, even if one accepts for the sake of argument that the Secretary has the authority to approve the sort of state $\S 1115$ demonstration projects under the section's expenditure authority as described in Spry and Newton-Nations, CMS's HAO solicitation falls outside that scope. The ACA expansion population is a mandatory Medicaid population, not an optional one. ${ }^{161}$ Congress expanded Medicaid benchmark benefits to adults earning less than $133 \%$ of the federal poverty level in the portion of the statute describing mandatory

154. Div. OF HeAlthCARE Fin., supra note 76, at 2-3.

155. Wall Street Journal, supra note 59.

156. See Letter from Mary C. Mayhew, supra note 148, at 7; see also Petition for Writ of Certiorari, supra note 144, at 24 ("The community engagement requirements may impact overall coverage levels if the individuals subject to the requirements choose not to comply with them. However, the demonstration as a whole is expected to provide greater access to coverage for lowincome individuals than would be available absent the demonstration. It furthers the Medicaid program's objectives to allow states to experiment with innovative means of deploying their limited state resources in ways that may allow them to provide services beyond the legal minimum. Enhancing fiscal sustainability allows the state to provide services to Medicaid beneficiaries that it could not otherwise provide." (quoting Letter from Mary C. Mayhew, supra note 148, at 7)).

157. 42 U.S.C. $\$ 1396 a(a)(10)(A)(i)(V I I I)$.

158. Nat'l Fed'n Indep. Bus. v. Sebelius, 567 U.S. 519, 585 (2012).

159. Stewart v. Azar, 366 F. Supp. 3d 125, 153 (D.D.C. 2019) (citing NFIB, 567 U.S. at 585).

160. Id. at 154 .

161. 42 U.S.C. $§ 1396 a(a)(10)(A)(i)(V I I I) ; ~ 42$ C.F.R. $\S 435.119$ (b). 
populations. ${ }^{162}$ The Department of Health and Human Services promulgated regulations requiring states to include this population in their state plans. ${ }^{163}$ Even under Spry and Newton-Nations, it is outside the scope of the Secretary's authority to treat this population as ineligible for Medicaid outside the confines of a waiver. ${ }^{164}$

There also remains the question of the Secretary's authority to cap federal matching funds for any population under the Secretary's $\S 1115$ authority. Medicaid's expenditure authority is found in 42 U.S.C. $§ 1396 b .{ }^{165}$ It provides in relevant part:

From the sums appropriated therefor, the Secretary (except as otherwise provided in this section) shall pay to each State which has a plan approved under this subchapter, for each quarter ... - -

(1) an amount equal to the Federal medical assistance percentage of the total amount expended during such quarter as medical assistance under the State plan"166

The FMAP for services provided to most Medicaid beneficiaries in the fifty states "shall be 100 per centum less the State percentage," and by statute after subtracting the state percentage may total no less than fifty percent and no more than eighty-three percent. ${ }^{167}$ The FMAP for the ACA expansion population is statutorily set even higher, at ninety percent. ${ }^{168}$

The Secretary has no authority to waive the FMAP under $\S 1115$. Those provisions are found in $\S \S 1396 \mathrm{~b}$ and $1396 \mathrm{~d}$ of the Act, and under $\S 1115$, the Secretary's waiver authority extends only to $\S 1396 a .{ }^{169}$ Even CMS under the Trump administration ultimately refrained from pushing its legal interpretation this far. ${ }^{170}$ Proponents of block grants may nevertheless argue that, in fact, no

162. 42 C.F.R. $\S 435.119(b)$.

163. Id.

164. See Spry, 487 F.3d at 1277; Newton-Nations, 660 F.3d at 375, 380-81.

165. 42 U.S.C. $\$ 1396 \mathrm{~b}(\mathrm{a})(1)$.

166. $I d$.

167. 42 U.S.C. $\S 1396 \mathrm{~d}(\mathrm{~b})$

168. Id. $\S 1396 \mathrm{~d}(\mathrm{y})(1)(\mathrm{e})$.

169. Id. $\S 1396 \mathrm{~b}(\mathrm{a}), 1396 \mathrm{~d}(\mathrm{~b}) ; 42$ U.S.C. $\S 1315(\mathrm{a})(1)$.

170. Letter from Seema Verma, Adm'r, Ctrs. for Medicare \& Medicaid Servs., to Stephen Smith, Dir. of TennCare (Jan. 8, 2021), https://www.medicaid.gov/medicaid/section-1115demonstrations/downloads/tn-tenncare-ii-cms-demo-appvl-01082021.pdf ("The comments [on the TennCare Amendment 42 Waiver Application] correctly note that section 1115 does not give the Secretary authority to alter the medical assistance matching rate under section 1903, stating that ‘. . giving Tennessee a lump sum of federal funds isn't allowable[... .] CMS understands these concerns and is not approving the 'block grant' financing approach the state described in its original application. Tennessee's financing structure under this demonstration uses an aggregate cap budget neutrality financing approach that is consistent with existing CMS policy outlined in the 'Budget Neutrality Policies for Section 1115(a) Medicaid Demonstration Projects' SMDL \#18-009. Under this approach, the state will be subjected to a budget neutrality limit on the federal matching funds 
such waiver is required, since $\S 1396 \mathrm{~b}$ (a) provides only to "medical assistance under the State plan," yet $\S 1115$ demonstration projects are governed not by the state plan but rather by the waiver special terms and conditions. ${ }^{171}$ Thus - so the argument would go-expenditures under a $\S 1115$ demonstration project are not subject to the strictures of $\S 1396 \mathrm{~b}$, or at least not those expenditures for expansion populations not otherwise covered under the state plan. ${ }^{172}$ Again assuming for the sake of argument that this is correct, it still faces the problem raised earlier: the ACA expansion population is a mandatory Medicaid population, not an optional or entirely uncovered one. ${ }^{173}$ The Supreme Court in $N F I B v$. Sebelius prohibited the Secretary from withholding any more than matching funds for the ACA expansion population if a state fails to include that population in its state plan. ${ }^{174}$ By doing so, however, the Court did not thereby render that population "optional," but simply altered the penalty for failing to cover them. ${ }^{175}$ It is simply untenable for the Secretary to cap the FMAP for the ACA expansion population through a $\S 1115$ demonstration project.

it receives under the expenditure authority under section 1115(a)(2). To the extent the state exceeds the budget neutrality limit, federal matching under section 1115(a)(2) would be disallowed for that excess amount. Conversely, to the extent the state's expenditures turn out to be below the budget neutrality limit, the state can share in the savings achieved.").

171. See, e.g., Appellee's Joint Brief at 6, 30, Cookeville Reg'1 Med. Ctr. v. Leavitt, 521 F.3d 844 (D.C. Cir. 2008) (Nos. 07-5252 \& 07-5269) (quotation marks omitted) (quoting 42 U.S.C. $\S \S$ $1396 \mathrm{~b}(\mathrm{a})(1), 1396 \mathrm{~d}(\mathrm{~b}))$ (stating that "a demonstration project is not 'approved under subchapter XIX'; it is approved under section 1115 of the Social Security Act, 42 U.S.C. $§ 1315$, which is a part of Subchapter XI. The demonstration project statute, in fact, acknowledges that its programs are not a part of subchapter XIX, but that the Secretary may approve a 'demonstration project which ... is likely to assist in promoting the objectives of subchapter ... XIX.' A demonstration project is distinct from a basic Medicaid plan in important respects. In addition to the fact that the Secretary can waive Medicaid income and resource eligibility limits for demonstration projects, such projects also are approved pursuant to different statutory provisions, they are approved under a different process, and they are governed by a separate coverage plan document." (footnote omitted) (citation omitted)).

172. Cf. Newton-Nations v. Betlach, 660 F.3d 370, 375, 379 (9th Cir. 2011) (providing that expenditures under a $\S 1115$ demonstration project for populations not otherwise included in the state plan are merely "regard[ed]. . . as expenditures under the state plan" for the purpose of obtaining federal Medicaid matching funds, but not for other purposes (emphasis added)).

173. See supra note 157 and associated text.

174. Nat'l Fed'n of Indep. Bus. v. Sebelius, 567 U.S. 519, 585-86 (2012) ("In light of the Court's holding, the Secretary cannot apply $\S 1396 \mathrm{c}$ to withdraw existing Medicaid funds for failure to comply with the requirements set out in the expansion. That fully remedies the constitutional violation we have identified. The chapter of the United States Code that contains § 1396c includes a severability clause confirming that we need go no further.").

175. Id. at 585 (discussing how the Secretary may withhold federal Medicaid funds from states that fail to comply with Medicaid requirements, including those in the expansion). 


\section{OTHER CONSIDERATIONS}

Whether the proposed caps are legal or illegal, it is dismaying that, even in the face of the pandemic, CMS has not withdrawn its HAO solicitation or its grant of a modified form of Tennessee's demonstration as of June 2021, and that the state of Utah continues to seek its per capita cap demonstration. ${ }^{176}$ One would expect that even a partisan committed to the elimination of public assistance for most people under most circumstances would concede that an exception could be made during a deadly global pandemic with catastrophic health and economic consequences, but CMS under Administrator Verma did not, nor yet has the Biden administration. It is not that CMS has ignored the effects of the pandemic. Quite the contrary, it has taken many steps, including relaxing Medicare regulations that hindered the delivery of health care through telemedicine and other distanced means, ${ }^{177}$ increasing sites for coronavirus testing, ${ }^{178}$ and granting $\S 1115$ COVID-19-related Medicaid waivers for states. ${ }^{179}$

CMS's continued solicitation during the pandemic of $\S 1115$ applications seeking to block-grant or per-capita-cap federal expenditures for non-elderly, non-disabled adults in exchange for greater programmatic and financial flexibilities is in keeping with other choices the Trump administration made during the pandemic. Despite a significant increase in unemployment and a second wave of job losses, the Trump administration petitioned the Supreme Court to review Gresham v. Azar and Philbrickv. Azar, in which the D.C. Circuit affirmed the district court's decision to vacate the Secretary's grant of Arkansas'

176. LYNCH, supra note 14, at 1; Medicaid Waiver Tracker: Approved and Pending Section 1115 Waivers by State, KAISER FAM. FOUND. (Mar. 18, 2021), https://www.kff.org/medicaid/issuebrief/medicaid-waiver-tracker-approved-and-pending-section-1115-waivers-by-state/.

177. See, e.g., COVID-19 Emergency Declaration Blanket Waivers for Health Care Providers, CTRS. FOR MEDICARE \& MEDICAID SERVS. 5, 37 (Apr. 8, 2021), https://www.cms.gov/files /document/summary-covid-19-emergency-declaration-waivers.pdf (summarizing the blanket waivers CMS made that do not require submission of a $\S 1135$ waiver request).

178. See, e.g., Press Release, U.S. Dep't of Health \& Hum. Servs., Trump Administration Announces Initiative for More and Faster COVID-19 Testing in Nursing Homes (July 14, 2020), https:/www.hhs.gov/about/news/2020/07/14/trump-administration-announces-initiative-morefaster-covid-19-testing-nursing-homes.html (announcing "a large-scale procurement of U.S. Food and Drug Administration (FDA) -authorized rapid point-of-care diagnostic test instruments and tests to be distributed to nursing homes").

179. E.g., Letter from Judith Cash, State Demonstrations Grp. Dir., Ctrs. for Medicare \& Medicaid Servs., to Kate McEvoy, Medicaid Dir., Conn. Dep’t of Soc. Servs. (June 15, 2020), https://www.medicaid.gov/medicaid/section-1115-demonstrations/downloads/ct-covid-19-phestate-ltr.pdf (detailing requested flexibilities that CMS is granting for the duration of the public health emergency); Letter from Seema Verma, Adm'r, Ctrs. for Medicare \& Medicaid Servs., to Henry Lipman, Medicaid Dir., New Hampshire Dep't of Health \& Hum. Servs. (May 29, 2020), https://www.medicaid.gov/medicaid/section-1115-demonstrations/downloads/nh-covid-19-pheca.pdf (detailing CMS's approval of New Hampshire's COVID-19 Public Health Emergency $\S$ 1115(a) demonstration). 
and New Hampshire's Medicaid work requirement $\S 1115$ demonstration applications. ${ }^{180}$ In regulations promulgated in fall of 2020, CMS opted to not cover COVID-19 testing, treatment, or immunizations for populations eligible only for limited Medicaid benefits, and to exclude from the Families First Coronavirus Relief Act continuous coverage for those beneficiaries deemed to be "not validly enrolled." 181 Meanwhile, the administration argued in November 2020 before the Supreme Court that the Tax Cuts and Jobs Act of 2017 rendered the Affordable Care Act's individual mandate unconstitutional, and that the ACA should accordingly be invalidated. ${ }^{182}$

All this presumably has been done, at least in part, to help "return" Medicaid to its "original" purpose, in Administrator Verma's words. ${ }^{183}$ Yet, as detailed in the first section of this Article, it has been many decades since Medicaid has looked anything like it did when it was originally enacted. ${ }^{184}$ Medicaid changed over time to meet the changing needs of states and populations. It expanded to improve and protect the health of families and children, and to cover low-income workers who, in the absence of Medicaid eligibility, had unstable and uncertain access to coverage at best. ${ }^{185}$ Its benefit structure also changed to allow states the option to cover non-elderly, non-disabled adults and children with benchmark benefits resembling those found in common private plans. ${ }^{186}$ Meanwhile, the employer-sponsored coverage that Administrator Verma claims is more "suitable" for the ACA Medicaid expansion population changed, too, both by becoming more scarce as a benefit of employment and by offering a more complete panoply of benefits that more closely resembles the set of

180. Petition for Writ of Certiorari at 1, Azar v. Gresham, No. 20-37 (U.S. July 13, 2020).

181. Sara Rosenbaum et al., Administration Effectively Rescinds 'Families First' Medicaid Continuous Enrollment Protection, Health AfFs.: HeAlth AfFs. Blog (Nov. 18, 2020), https://www.healthaffairs.org/do/10.1377/hblog20201116.26547/full/.

182. Transcript of Oral Argument at 5, California v. Texas, No. 19-1019 (Nov. 10, 2020).

183. See Wall Street Journal, supra note 59 (discussing how expanding Medicaid to cover ablebodied adults stretches the social net at the expense of those for whom the program was originally intended).

184. Supra notes 23-27, 29-31 and accompanying text.

185. Jessica Schubel, Ctr. ON Budget \& Pol'y Priorities, EXPANDing MEdiCAid For PARENTS IMPROVES COVERAGE AND HEALTH FOR BOTH PARENTS AND CHILDREN 2 (2020) (reporting that children whose parents became eligible to receive Medicaid under the ACA's expansion also gained Medicaid coverage at a rate more than double that of their peers in nonexpansion states); Rachel Garfield et al., The Coverage Gap: Uninsured Poor Adults in States that Do Not Expand Medicaid, KAISER FAM. Found. (Jan. 21, 2021), https://www.kff.org/medic aid/issue-brief/the-coverage-gap-uninsured-poor-adults-in-states-that-do-not-expand-medicaid/.

186. Sara Rosenbaum et al., Medicaid Benefit Designs for Newly Eligible Adults: State Approaches, THE COMMONwEALTH Fund 1-2 (May 2015), https://www.commonwealthfund.org $/$ sites/default/files/documents/__media_files_publications_issue_brief_2015_may_1815_rosen baum_medicaid_benefit_designs_newly_eligible_adults.pdf (discussing both Medicaid and CHIP's use of benchmark plans). 
benefits available to Medicaid populations than those offered by employers in the 1960s and ' 70 s. ${ }^{187}$

In short, times have changed. Both Medicaid and private coverage have changed. Any attempt to return Medicaid to some alleged version of the past ignores this metamorphosis. It ignores present needs, needs that have been both amplified and magnified by the current pandemic. It furthermore ignores salient features of the law. Merely because HHS has previously granted $\S 1115$ demonstration projects that have capped federal matching funds, at least in theory, does not therefore mean that such projects are legal. Absence of legal challenge does not confer legality. Demonstration solicitations such as the Healthy Adult Opportunity initiative that seek to limit coverage and elide protections for beneficiaries are unlawful and should have no place in our federal health policy.

187. Id. at 1 (pointing out that Medicaid plans use private insurance benefits as a benchmark, so those who are covered by either Medicaid or private insurance receive similar benefits); Wall Street Journal, supra note 59 (explaining her goal to structure the Medicaid program so that ablebodied adults can exit the program and obtain another job that provides health insurance); Jennifer Tolbert et al., Key Facts About the Uninsured Population, KAISER FAM. FOund. (Nov. 6, 2020), https://www.kff.org/uninsured/issue-brief/key-facts-about-the-uninsured-population/ (emphasizing the disconnect between employment and health insurance coverage, as highlighted in 2019 , when $73.2 \%$ of uninsured people had at least one full-time worker in the family, while another $11.5 \%$ had a part-time worker); Walter W. Kolodrubetz, Two Decades of Employee-Benefit Plans, 1950-1970: A Review, 35 Soc. SEC. BuLl. 10, 11 (1972), https://www.ssa.gov/policy/docs $/ \mathrm{ssb} / \mathrm{v} 35 \mathrm{n} 4 / \mathrm{v} 35 \mathrm{n} 4 \mathrm{p} 10 . p d f$ (noting how employer-sponsored health insurance primarily covered hospital and in-hospital surgery expenses in the $1950 \mathrm{~s}$, but that coverage expanded over time). 


\title{
Mitchell Hamline Open Access
}

Mitchell Hamline Open Access is the digital archive of Mitchell Hamline School of Law. Its mission is to preserve and provide access to our scholarly activities, for the benefit of researchers and members of the legal community.

Mitchell Hamline Open Access is a service of the Warren E. Burger Library.

open.mitchellhamline.edu

\author{
$\mathrm{MH}$ \\ MITCHELL | HAMLINE \\ School of Law \\ (C) Mitchell Hamline School of Law \\ 875 Summit Avenue, Saint Paul, MN 55105 \\ mitchellhamline.edu
}

